\title{
11. PALEOGENE CALCAREOUS NANNOPLANKTON FROM THE SOUTHWEST PACIFIC OCEAN, DEEP SEA DRILLING PROJECT, LEG $90^{1}$
}

\author{
Erlend Martini, Geologisch-Paläontologisches Institut der Universität, Frankfurt am Main²
}

\begin{abstract}
The positions of all cores recovered during Leg 90 in the southwest Pacific are shown within the standard calcareous nannoplankton zonation. The stratigraphic and regional occurrences and preservation of Paleogene calcareous nannoplankton found at Sites 588, 592, and 593 are discussed, and fossil lists are given for selected samples. Data on the Eocene/Oligocene boundary found in Holes 592 and 593 and on the Oligocene/Miocene boundary in Hole 588C are presented. Regional unconformities are noted in Hole 588C, where the upper Eocene to middle Oligocene interval (Zones NP17 to NP23) is missing, and in Hole 592, in which the middle Oligocene to lowest Miocene interval (Zones NP23 to NN1) is not represented.
\end{abstract}

\section{INTRODUCTION}

During Leg 90 of the Deep Sea Drilling Project, eight sites (587 to 594) were occupied and 18 holes drilled in the New Caledonia to New Zealand region (Fig. 1). All holes yielded common calcareous nannoplankton. Results for each hole are summarized and cores are located within the standard calcareous nannoplankton zonation in Table 1 .

Holes 588C, 592, 593, and 593A yielded Paleogene calcareous nannoplankton. The Paleogene assemblages of these holes and their age assignments are discussed below. Fossil lists for selected samples from Holes 588C, 592 , and 593 are presented in Tables 2 to 4 , covering most of the middle Eocene to upper Oligocene interval. For the Neogene and Quaternary calcareous nannoplankton found during Leg 90 see Lohman, this volume.

\section{CALCAREOUS NANNOPLANKTON ZONATION}

For the Tertiary and Quaternary the standard calcareous nannoplankton zonation (Martini, 1971) is used. For the Paleogene nannoplankton zones some deviations are necessitated by the high latitudes of some of the Leg 90 sites (Fig. 2).

\section{NP24/NP25* (combined Sphenolithus distentus/} S. ciperoensis Zone) ${ }^{3}$

Substitute definition. Interval from the last occurrence of Blackites tenuis (Bramlette and Sullivan) to the last occurrence of Zygrhablithus bijugatus (Deflandre).

Remarks. As sphenoliths commonly used to define the zonal boundaries in the middle and late Oligocene are too rare or missing in samples from Holes 593 and 593A because of its high latitude during the Paleogene,

\footnotetext{
${ }^{1}$ Kennett, J. P., von der Borch, C. C., et al., Init. Repts. DSDP, 90: Washington (U.S. Govt, Printing Office).

2 Address: Geologisch-Paläontologisches Institut der Universität, Senckenberg-Anlage 32-34, D6000 Frankfurt am Main, Federal Republic of Germany.

3 Superscript asterisk indicates that top marker species has been changed, subscript asterisk that base marker species has been changed.
}

the two uppermost Paleogene nannoplankton zones had to be combined and the substitute species noted had to be used. The last occurrence of $B$. tenuis (Bramlette and Sullivan) is taken as the base of Zone NP24 in these holes, because in high latitudes it seems not to cross the NP23/NP2 4 boundary. The NP25/NN1 boundary is placed at the last occurrence of $Z$. bijugatus (Deflandre), as on the high latitude Legs 38 (Müller, 1976) and 49 (Martini, 1979).

\section{NP 23* (Sphenolithus predistentus Zone)}

Substitute definition. Interval from the last occurrence of Reticulofenestra umbilica (Levin) to the last occurrence of Blackites tenuis (Bramlette and Sullivan).

Remarks. Because of the high latitude of Hole 593 during the Paleogene, sphenoliths are commonly rare or missing, and the top of Zone NP23 in this case is defined by the last occurrence of $B$. tenuis (Bramlette and Sullivan) as discussed above.

\section{NP19/NP20 (combined Isthmolithus recurvus/Sphenolithus pseudoradians Zone)}

Definition. Interval from the first occurrence of Isthmolithus recurvus Deflandre to the last occurrence of Discoaster saipanensis Bramlette and Riedel.

Remarks. Sphenolithus pseudoradians Bramlette and Wilcoxon, the index species for the base of Zone NP20, first occurred in the equatorial Pacific much earlier than in high latitudes (Bukry, 1971), and differentiation is possible only in middle latitudes (Martini, 1981a). For the present area it seems more realistic to combine Zones NP19 and NP20.

\section{NP15/NP16 (combined Chiphragmalithus alatus/Discoaster tani nodifer Zone)}

Definition. Interval from the first occurrence of Chiphragmalithus alatus (Martini) to the last occurrence of Chiasmolithus solitus (Bramlette and Sullivan).

Remarks. In Hole 588C the index species of the boundary between Zones NP15 and NP16-Blackites gladius (Locker) - was not found (probably it is a nearshore spe- 


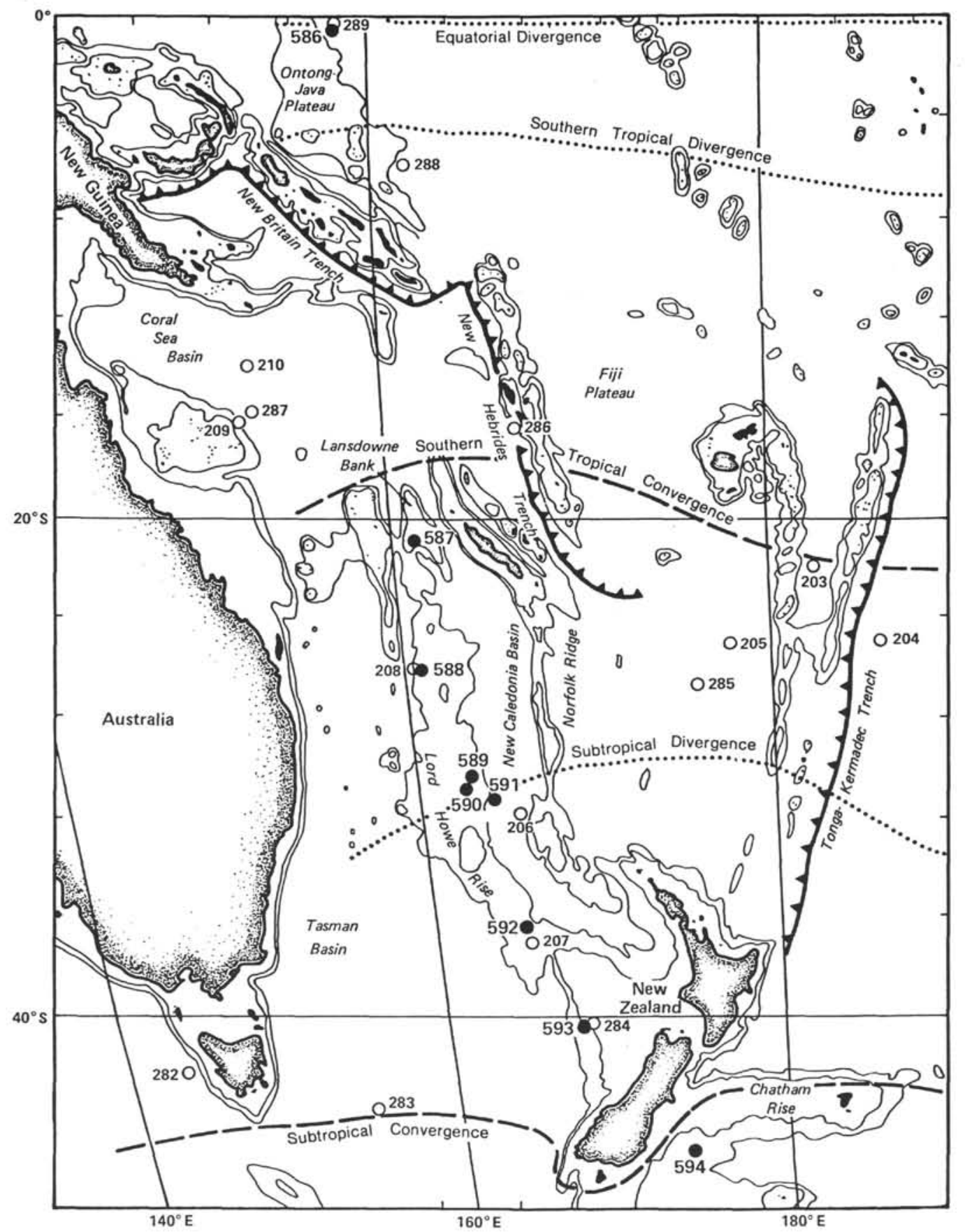

Figure 1. Location of sites drilled during Leg 90 (solid circles) and other DSDP drill sites (open circles) in the southwest Pacific.

cies), and the only occurrence of Chiphragmalithus alatus is in Sample 588C-18-1, middle. Therefore a combination of the two zones for this hole seems necessary. However, a single specimen of Chiasmolithus gigas (Bramlette and Sullivan) was noted in Sample 588C-19-1, 10$12 \mathrm{~cm}$, and the whole sequence between Samples 588C$18-1$, middle, to $588 \mathrm{C}-19, \mathrm{CC}$ may belong in Zone NP15 (Chiphragmalithus alatus Zone). The sequence could be in a position within this interval similar to the Chiasmolithus gigas Subzone of Bukry (1973).

\section{SITE SUMMARIES}

Site $588\left(26^{\circ} 06.7^{\prime} \mathrm{S}, 161^{\circ} 13.6^{\prime} \mathrm{E}\right.$, water depth $\left.1533 \mathrm{~m}\right)$

In Hole $588 \mathrm{C}$, on the northern part of Lord Howe Rise, Paleogene sediments were encountered form Core 6 (353.7 $\mathrm{m}$ sub-bottom) downward to the terminal depth of $488.1 \mathrm{~m}$ in Core 19. The interval between Samples $588 \mathrm{C}-6-2,0-1 \mathrm{~cm}$ and $588 \mathrm{C}-17-1,0-1 \mathrm{~cm}$ is placed in standard nannoplankton Zone NP25 (Sphenolithus ciperoensis Zone). Important species include Helicosphae- 
Table 1. Calcareous nannoplankton stratigraphy of Holes 586-594.

\begin{tabular}{|c|c|c|c|c|c|c|c|c|c|c|c|c|c|c|c|c|c|c|c|c|}
\hline & SNZ & $586 \mathrm{~B}$ & 587 & 588 & $588 \mathrm{~A}$ & $588 \mathrm{~B}$ & $588 \mathrm{C}$ & 589 & 590 & $590 \mathrm{~A}$ & $590 \mathrm{~B}$ & 591 & $591 \mathrm{~A}$ & $591 \mathrm{~B}$ & 592 & 593 & $593 \mathrm{~A}$ & 594 & $594 \mathrm{~A}$ & 594B \\
\hline \multirow{3}{*}{ Quaternary } & NN21 & 1 & \multirow{2}{*}{$1-3$} & 1 & & 1 & & 1 & 1 & & 1 & 1 & 1 & & 1 & 1 & 1 & $1-6$ & 1 & $1-5$ \\
\hline & $\mathrm{NN} 20$ & 1 & & 1 & & 1 & & 1 & 1 & & $1-2$ & $1-2$ & 1 & & 1 & $1-2$ & 1 & 6-7 & 2 & \\
\hline & NN19 & $1-5$ & $3-4$ & $1-3$ & & $1-2$ & & $1-4$ & $2-3$ & 1 & $2-4$ & $2-6$ & $2-5$ & & $2-3$ & $2-5$ & $2-4$ & $7-11$ & (3)-5 & \\
\hline \multirow{3}{*}{$\begin{array}{l}\text { upper Pliocene } \\
\text { (Piacenzian) }\end{array}$} & NN18 & $5-6$ & 4 & 3-4 & & 3 & & 4 & & 2 & $5-6$ & $6-8$ & $6-7$ & & 3-4 & 6 & (5) & \multirow{3}{*}{$11-18$} & \multirow{3}{*}{$6-9$} & \\
\hline & NN17 & 6 & 4 & 4 & & (4) & & & & 3 & 6 & 8 & (8) & & 4 & 6 & (5) & & & \\
\hline & NN16 & $6-9$ & 5 & 4-6 & & 4-5 & & & & 3-7 & $6-9$ & $8-12$ & $8-11$ & & $4-6$ & $6-8$ & $5-7$ & & & \\
\hline \multirow{4}{*}{$\begin{array}{l}\text { lower Pliocene } \\
\text { (Zanclian) }\end{array}$} & NN15 & $9-13$ & $5-6$ & $6-9$ & & $6-8$ & & & & $7-11$ & $10-14$ & $12-16$ & $12-15$ & & $6-8$ & 9 & $8-12$ & $18-20$ & 10 & \\
\hline & $\mathrm{NN} 14$ & $13-15$ & 6-7 & 9-11 & & $8-9$ & & & & $11-14$ & $15-16$ & $17-20$ & $16-20$ & & $8-13$ & $11-13$ & \multirow{3}{*}{$13-16$} & \multirow{3}{*}{$20-23$} & \multirow{3}{*}{11} & \\
\hline & $\mathrm{NN} 13$ & 15 & 7 & 11 & & 9 & & & & 14-16 & $17-18$ & 21 & $21-22$ & & \multirow{2}{*}{14} & \multirow{2}{*}{$14-17$} & & & & \\
\hline & $\mathrm{NN} 12$ & $16-17$ & 7 & $11-12$ & & 9-11 & & & & $16-18$ & $19-20$ & $21-24$ & 23 & & & & & & & \\
\hline \multirow{3}{*}{$\begin{array}{l}\text { upper Miocene } \\
\text { (Tortonian- } \\
\text { Messinian) }\end{array}$} & NN11b & $18-21$ & $7-10$ & $12-18$ & & $12-17$ & & & & $18-27$ & $21-30$ & $24-28$ & $24-27$ & & $15-17$ & $17-22$ & $17-20$ & \multirow{2}{*}{$23-26$} & & \\
\hline & NNIla & $21-25$ & 10-11 & $18-20$ & & 18-19 & & & & & $30-35$ & $28-31$ & $28-30$ & $1-4$ & $18-19$ & $22-25$ & $21-22$ & & & \\
\hline & NN10 & & & $20-23$ & & $20-22$ & & & & & $35-38$ & & & $5-8$ & $19-20$ & $25-26$ & & $26-28$ & & \\
\hline \multirow{5}{*}{$\begin{array}{l}\text { middle Miocene } \\
\text { (Langhian- } \\
\text { Serravallian) }\end{array}$} & NN9 & & & $23-25$ & & $23-25$ & & & & & $38-40$ & & & $9-11$ & $21-22$ & $26-27$ & & $28-29$ & & \\
\hline & NN8 & & & 25 & 1 & 26 & & & & & 41 & & & 11 & 23 & \multirow{2}{*}{ 28-37 } & & \multirow{2}{*}{$30-42$} & & \\
\hline & NN7 & & & 25 & $1-2$ & $27-29$ & & & & & $42-45$ & & & 12 & $23-24$ & & & & & \\
\hline & NN6 & & & & $2-8$ & $30-31$ & & & & & $45-47$ & & & $13-18$ & $25-28$ & $37-42$ & & $42-53$ & $12-15$ & \\
\hline & NN5 & & & & $9-13$ & & & & & & $47-49$ & & & $18-23$ & $28-29$ & $42-43$ & & & $15-26$ & \\
\hline \multirow{4}{*}{$\begin{array}{l}\text { lower Miocene } \\
\text { (Aquitanian- } \\
\text { Burdigalian) }\end{array}$} & $\mathrm{NN} 4$ & & & & $13-15$ & & $1-2$ & & & & 50 & & & $24 ?$ & $29-31$ & 44 & & & & \\
\hline & NN3 & & & & $16-17$ & & $2-3$ & & & & $51-52$ & & & & $31-32$ & 44-46 & & & & \\
\hline & NN2 & & & & 18 & & 3-5 & & & & $52-53$ & & & & $32-33$ & 46 & & & & \\
\hline & NN1 & & & & & & 5 & & & & & & & & & $47-50$ & 23-24 & & & \\
\hline upper Oligocene & NP25 & & & & & & $6-17$ & & & & & & & & & \multirow{2}{*}{$50-55$} & \multirow{2}{*}{ 24-27 } & & & \\
\hline & NP24 & & & & & & $17-18$ & & & & & & & & & & & & & \\
\hline (Rupelian) & NP23 & & & & & & & & & & & & & & & $55-56$ & & & & \\
\hline \multirow{2}{*}{$\begin{array}{l}\text { lower Oligocene } \\
\text { (Latdorfian) }\end{array}$} & NP22 & & & & & & & & & & & & & & $33-34$ & $56-57$ & & & & \\
\hline & NP21 & & & & & & & & & & & & & & $35-37$ & $57-58$ & & & & \\
\hline & NP20 & & & & & & & & & & & & & & \multirow{2}{*}{$37-41$} & 5960 & & & & \\
\hline upper Eocene & NP19 & & & & & & & & & & & & & & & $39-60$ & & & & \\
\hline Priabonian) & NP18 & & & & & & & & & & & & & & & & & & & \\
\hline & NP17 & & & & & & & & & & & & & & & & & & & \\
\hline & NP16 & & & & & & $18-19$ & & & & & & & & & & & & & \\
\hline $\begin{array}{l}\text { middle Eocene } \\
\text { (Lutetian) }\end{array}$ & NP15 & & & & & & $70-18$ & & & & & & & & & & & & & \\
\hline & NP14 & & & & & & & & & & & & & & & & & & & \\
\hline
\end{tabular}

Note: Numbers refer to cores. Hiatuses in black. SNZ $=$ standard nannoplankton zone.

ra recta and Zygrhablithus bijugatus, which both last occur in Sample 588C-6-2, 0-1 cm, although the latter species occurs only sporadically. Dictyococcites dictyo$d u s$ is present throughout this interval and is last noted in Sample 588C-4-5, 0-1 cm, of early Miocene age. Discolithina enormis and $S$. ciperoensis are rare or few and which last occur well below the Oligocene/Miocene boundary, which in this hole is defined by the last occurrences of $H$. recta (Table 2). Triquetrorhabdulus carinatus and $S$. dissimilis, both crossing the Oligocene/Miocene boundary, first occur in the lower part of Zone NP25. Triquetrorhabdulus milowii, which has a range from the base of Zone NP25 to the top of Zone NN1 in the Philippine Sea (Martini, 1980), seems to be restricted to the higher parts of Zone NP25 and lower part of Zone NN1 (last occurrence in Sample 588C-5-4, 0-1 cm) at Site 588. The interval between Sample 588C-17-3, $0-1 \mathrm{~cm}$ and $588 \mathrm{C}-18-1$, top, belongs to nannoplankton Zone NP24 (S. distentus Zone), with the nominate species as well as $S$. predistentus and Coccolithus abisectus present. A hiatus was noted between Samples 588C-18-1, top, and $588 \mathrm{C}-18-1$, middle part, dividing Zone NP24 and the combined Zones NP15/NP16, with the upper middle Eocene to middle Oligocene missing. Important species for the middle Eocene Zones NP15/NP16 include Neococcolithes dubius, S. furcatolithoides, Chiasmolithus solitus, and Chiphragmalithus alatus, which was noted in Sample 588C-18-1, middle. Above the hiatus reworked Eocene nannoplankton specimens were found in several samples (Table 2). Also reworked Paleogene species (Fasciculithus sp. and Neochiastozygus concinnus) were noted in Sample 588C-14-3, 0-1 cm, and Upper Cretaceous species (e.g., Arkhangelskiella cymbiformis) were found in Sample 588C-12-3, 0-1 cm.

Preservation of the Paleogene calcareous nannoplankton in Hole $588 \mathrm{C}$ varies from poor to moderate in white to light gray to light greenish gray foraminifer-bearing nannofossil chalk of late Oligocene age and in light greenish gray siliceous foraminifer-bearing nannofossil chalk of middle Eocene age. Discoasters, especially in the Oligocene, are overcalcified, which is also true for some of the Oligocene Discolithina occurrences.

Site $592\left(3^{\circ} 28.40^{\prime} \mathrm{S}, 1^{\circ} 5^{\circ} 26.53^{\prime} \mathrm{E}\right.$, water depth $\left.1098 \mathrm{~m}\right)$

In Hole 592, situated on the southern part of the Lord Howe Rise, lower Oligocene (Zones NP21 and NP22) and upper Eocene (Zone NP19/NP20) sediments are present in the interval between Samples 592-33-3, $70 \mathrm{~cm}$ 


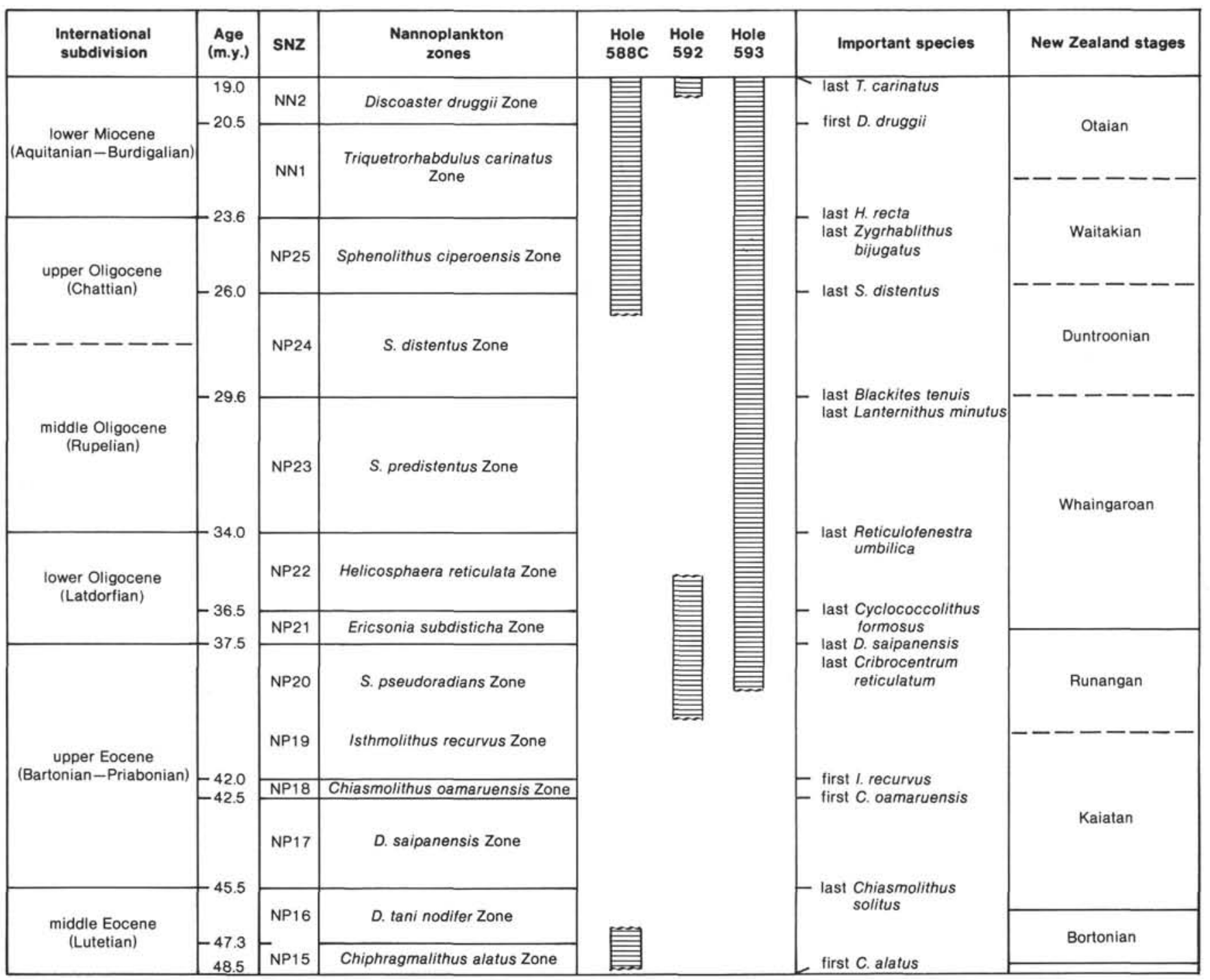

Figure 2. Middle Eocene to lowest Miocene standard nannoplankton zonation (SNZ) used during Leg 90, position of Paleogene cores from Sites 588,592 , and 593, first and last occurrences of important nannoplankton species, and New Zealand stages.

(305.8 $\mathrm{m}$ subbottom) and the terminal depth of $388.5 \mathrm{~m}$ in Sample 592-41,CC. Between Samples 592-33-3, $70 \mathrm{~cm}$ and 592-33-3, 5-6 cm a hiatus was identified, with the middle and upper Oligocene as well as the lowest Miocene missing.

The lower Oligocene Zones NP21 and NP22 were identified by the last occurrences of Discoaster saipanensis in Sample 592-37-2, 33-34 cm, Cycloccolithus formosus in Sample 592-35-1, 3-4 cm, and Reticulofenestra umbilica in Sample 592-33-3, $70 \mathrm{~cm}$. For the late Eocene, nannoplankton Zones NP19 and NP20 were combined because the guide species Sphenolithus pseudoradians is not present in this area. It was also shown to have no time-equivalent first occurrence in the oceans (Bukry, 1971; Martini, 1976). For details on the ranges of calcareous nannoplankton species see Table 3 .

Reworking of Eocene and Oligocene calcareous nannoplankton was noted in the lower Miocene above the hiatus. Reworked middle Eocene species, with Neococ- colithes dubius most conspicuous, occurred also in the lowest part of Hole 592, attributed to the upper Eocene Zone NP19/NP20.

Preservation is moderate throughout the Paleogene interval, which consists of white to very light gray nannofossil ooze in the early Oligocene (Cores 33 to 37 ) and white to very light gray nannofossil chalk in the late Eocene (Cores 38 to 41 ), but is only poor to moderate just below and above the hiatus.

\section{Site $593\left(40^{\circ} 30.47^{\prime} \mathrm{S}, 167^{\circ} 40.47^{\prime} \mathrm{E}\right.$, water depth $\left.1068 \mathrm{~m}\right)$}

Hole 593 on the Challenger Plateau to the west of New Zealand provided a continuous Paleogene sequence from Core 50 ( $\sim 472 \mathrm{~m}$ sub-bottom) down to the terminal depth of $571.5 \mathrm{~m}$ in Core 60 , including the upper Eocene and complete Oligocene. The Oligocene/Miocene boundary according to calcareous nannoplankton is placed between Samples 593-50-3, 3-4 cm and 593-50-5, 3-4 $\mathrm{cm}$ by the last occurrence of Zygrhablithus bijuga- 
tus, because Helicosphaera recta and most Sphenolithus species are too rare or are missing, because of the high latitude of this site in the Paleogene.

Standard nannoplankton Zones NP24* (Sphenolithus distentus Zone) and NP25* (S. ciperoensis Zone) had to be combined because of the lack of sphenoliths. The top of Zone NP23* (S. predistentus Zone) is defined by the last occurrence of Blackites tenuis and Lanternithus minutus in Sample 593-55,CC. The tops of Zones NP22 (Helicosphaera reticulata Zone) and NP21 (Ericsonia subdisticha Zone) were identified by the last occurrence of Reticulofenestra umbilica and Cyclococcolithus formosus, respectively. The Eocene/Oligocene boundary based on calcareous nannoplankton is obscured in Hole 593 because of the volcanogenic material in the lower part of Core 58 and most of Core 59. Sample 593-59,CC clearly belongs in the late Eocene nannoplankton Zone NP19/NP20 based on the occurrence of Cribrocentrum reticulatum, which does not cross the Eocene/Oligocene boundary (Müller, 1978). The ranges of calcareous nannoplankton species found are listed in Table 4.

Reworked middle Eocene nannoplankton species (e.g., Neococcolithes dubius) occur throughout Core 60, but were not found in Sample 593-59, CC and above. A similar occurrence of reworked middle Eocene species at Site 592 also ceased before the end of the Eocene. A few reworked Eocene specimens were found at several levels in the middle and upper Oligocene.

Preservation in the Oligocene varies between poor to moderate and moderate, with the best preservation in the lower and middle Oligocene white nannofossil ooze. Unlike the Oligocene interval, there is little difference in preservation between the Eocene light greenish gray chalk and the white nannofossil chalk that is interbedded with lithified volcanogenic turbidites in the interval from 59358-3 through Core 60.

In Hole 593A the late Oligocene calcareous nannoplankton Zone NP24/NP25* was encountered in Cores 24 (458.4 m sub-bottom) to the terminal depth of 496.8 $\mathrm{m}$ in Core 27; results duplicated those of part of Hole 593.

\section{EOCENE/OLIGOCENE BOUNDARY}

The Eocene/Oligocene boundary identified by means of the calcareous nannoplankton is commonly placed at the last occurrence of the rosette-shaped discoasters which dominate in the Eocene, especially the last occurrence of Discoaster saipanensis Bramlette and Riedel (top of Zone NP20) in deep sea sediments as well as in landbased sections (Martini, 1981b). The lower Oligocene (Latdorfian), including standard nannoplankton Zones NP21 and NP22, was clearly deposited prior to the Rupelian ( = middle Oligocene), which includes the standard calcareous nannoplankton Zones NP23 and part of NP24, although a quite misleading version was recently published in Harland et al. (1982), which has some forerunners in papers by Berggren (e.g., Hardenbol and Berggren, 1978), and is also used in a few DSDP papers. There are several articles discussing the time-equivalence of the Eocene/Oligocene boundary using calcareous nannoplankton and foraminifers (e.g., Bombita and Rusu,
1981; Snyder et al., 1984); they may be summarized by saying that the boundary defined by the planktonic foraminifers (commonly the last occurrence of Globorotalia cerroazulensis) is slightly younger than that drawn using calcareous nannoplankton.

This is also true for Sites 592 and 593, in which the Eocene/Oligocene boundary was encountered. At Hole 592 the boundary based on calcareous nannoplankton is between Samples 592-37-2, 5-6 cm and 592-37-2, 33-34 $\mathrm{cm}$, whereas based on planktonic foraminifers it is between Samples 592-36-3, $64 \mathrm{~cm}$ and 592-36-3, $90 \mathrm{~cm}$, where the last Globigerinatheka index were noted. A similar offset was observed in Hole 593, where the boundary based on calcareous nannoplankton lies between Samples 593-59,CC and 593-58-2, 110-112 cm, (although it is somewhat obscured by volcanogenic material deposited at the site at this time) and just above Sample 593$57, C C$, where $G$. index seems to have its last occurrence. At Site 593, discoasters are rare in the uppermost Eocene because of the position of Site 593 at that time, but are still noted in all samples just below the Eocene/Oligocene boundary (Table 4). However, the consistent presence of Cribrocentrum reticulatum (Gartner and Smith) up to Sample $593-59, \mathrm{CC}$ is a reliable datum placing the boundary somewhere in the volcanogenic sequence. The last occurrence of $C$. reticulatum has always been placed prior to the Eocene/Oligocene boundary (top of Zone NP20, last occurrence of D. saipanensis) in low and middle latitudes, and the species can be used as a reliable substitute in high latitudes.

With an accumulation rate of $19.0 \mathrm{~m} / \mathrm{m}$.y. in the early Oligocene that may also be true for the latest Eocene at Site 592, the time difference between the two boundary "events" is about $0.4 \mathrm{~m}$.y. No attempt is made to calculate the time difference at Site 593 because of the uncertainty of the nannoplankton-based Eocene/Oligocene boundary, which is somewhere within the volcanogenic interval.

\section{OLIGOCENE/MIOCENE BOUNDARY}

Continuous sequences across the Oligocene/Miocene boundary were recovered in Hole 588C and at Site 593. At Site 592 the boundary falls in a hiatus covering at least the interval between calcareous nannoplankton Zones NP23 (middle Oligocene) and NN1 (lower Miocene).

The Oligocene/Miocene boundary in terms of calcareous nannoplankton is generally placed at the top of standard nannoplankton Zone NP25 (Müller, 1981; Steininger, 1982), where several nannoplankton species have their last occurrences, for example Sphenolithus ciperoensis Bramlette and Wilcoxon, Helicosphaera recta (Haq), and Zygrhablithus bijugatus (Deflandre).

In Hole $588 \mathrm{C}$ the more delicate $S$. ciperoensis Bramlette and Wilcoxon and $S$. distentus (Martini) are rare, except in levels with moderate preservations, where they are better preserved. The last occurrence of $S$. ciperoensis in this hole is in Sample 588C-11,CC (Table 2), whereas $H$. recta and $Z$. bijugatus are found up to Sample $588 \mathrm{C}-6-2,0-1 \mathrm{~cm}$, although the latter are not continuously present and vary in frequency. Discolithina enormis Locker was noted in several samples up to Sample 
Table 2. Distribution of calcareous nannoplankton in selected samples from Hole 588C and indication of standard nannoplankton zones.

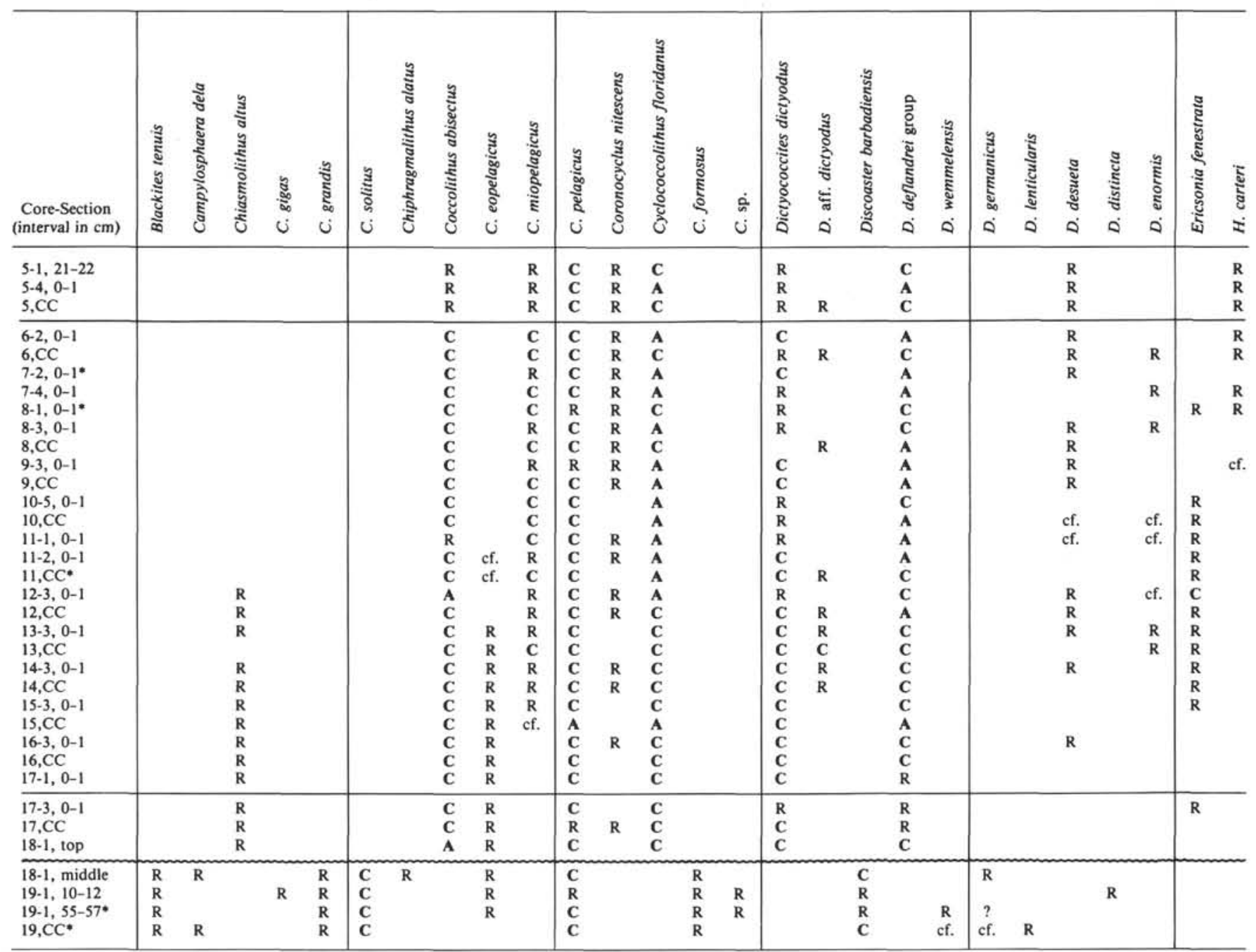

Note: $\mathbf{R}=$ rare to few, $\mathbf{C}=$ common, $\mathbf{A}=$ abundant. Preservation: $\mathbf{P}=$ poor, $\mathbf{M}=$ moderate, $\mathbf{G}=$ good. Reworking: $\mathrm{C}=$ Cretaceous, $\mathrm{P}=\mathrm{Paleocene}, \mathrm{E}=\mathrm{E}$.cene. ${ }^{*}=$ samples studied with scanning electron microscope.

588C-6,CC. Dictyococcites dictyodus (Deflandre) $[=R e-$ ticulofenestra bisecta (Hay, Mohler, and Wade) of some authors] and Discolithina desueta Müller range higher and have their last occurrences in Samples 588C-4-5, $0-1 \mathrm{~cm}$ and $588 \mathrm{C}-5-1,0-1 \mathrm{~cm}$, respectively. The Oligocene/Miocene boundary is taken to be just above Sample $588 \mathrm{C}-6-2,0-1 \mathrm{~cm}$ with the last occurrences of $H$. recta and $Z$. bijugatus. The foraminifer-based boundary is indicated in this hole by the first appearance of Globoquadrina dehiscens (see Srinivasan and Kennett, 1983), which is first noted in Sample 588C-8, CC, and is considerably lower than at Site 593 .

At Site 593 sphenoliths occur in a rather scattered fashion, except for S. moriformis (Brönnimann and Stradner), because of the position of this site at the time, and cannot be used as zonal markers. Helicosphaera species are rare and unreliable. The only species that occurs consistently and also commonly, indicating "shallow-water" conditions, is $Z$. bijugatus, which last occurs in Sample 593-50-5, 3-4 cm, and which is used in this hole to define the Oligocene/Miocene boundary in terms of cal- careous nannoplankton. Dictyococcites dictyodus ranges higher up, as it does in Hole 588C. Chiasmolithus altus Bukry and Percival, which is widespread in cold water masses, is found up to Sample 593-50,CC (Table 4), whereas it ceased at Site 588 in Sample 588C-12-3, 0-1 cm, well below the supposed Oligocene/Miocene boundary.

The first occurrence of the planktonic foraminifer $G$. dehiscens was noted in Sample 593-50-4, $90 \mathrm{~cm}$, and accordingly the Oligocene/Miocene boundary is placed between Samples 593-50-4, $90 \mathrm{~cm}$ and 593-50,CC, below the Oligocene/Miocene boundary based on calcareous nannoplankton. For further discussion see the biostratigraphic synthesis (Martini and Jenkins, this volume).

\section{REGIONAL UNCONFORMITIES}

In Leg 90 sites two major unconformities were noted in the Paleogene. One occurred in Hole $588 \mathrm{C}$ between Samples 588C-18-1, top and 588C-18-1, middle, dividing Zone NP24 and the combined Zone NP15/NP16, with the upper middle Eocene to middle Oligocene missing. In Hole 592 a hiatus was identified between Sam- 
Table 2. (Continued).

\begin{tabular}{|c|c|c|c|c|c|c|c|c|c|c|c|c|c|c|c|c|c|c|c|c|c|c|c|c|c|c|c|}
\hline हूँ & 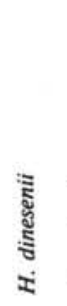 & 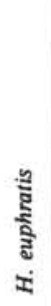 & 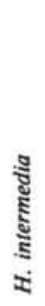 & $\begin{array}{l}\text { ¿ूँ } \\
\text { ¿ }\end{array}$ & 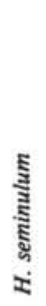 & 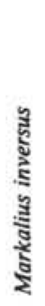 & 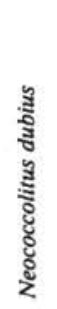 & 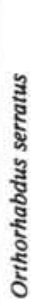 & 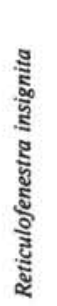 & 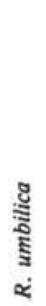 & 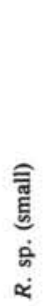 & 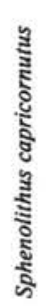 & 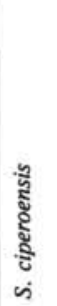 & 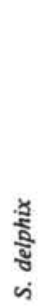 & 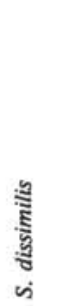 & 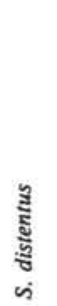 & 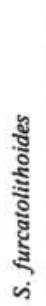 & 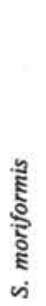 & 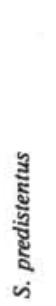 & $\begin{array}{l}\dot{\dot{n}} \\
\dot{v}\end{array}$ & 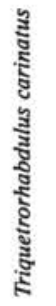 & $\begin{array}{l}\text { है } \\
\text { है } \\
\text { है } \\
\text { H }\end{array}$ & $\begin{array}{l}\text { है } \\
\text { है } \\
\text { है } \\
\text { N }\end{array}$ & 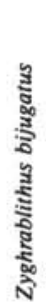 & $\begin{array}{l}\text { है } \\
\text { : } \\
\text { : } \\
\text { है }\end{array}$ & 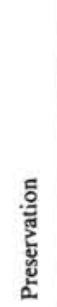 & $\begin{array}{c}\text { Standard } \\
\text { nannoplankton } \\
\text { zones }\end{array}$ \\
\hline & & $\begin{array}{l}R \\
R \\
R\end{array}$ & & & & & & $\mathbf{R}$ & $\mathbf{R}$ & & $\begin{array}{l}\text { C } \\
\text { C } \\
\text { C }\end{array}$ & & & & $\begin{array}{l}\mathbf{R} \\
\mathbf{R}\end{array}$ & & & $\begin{array}{l}\text { C } \\
\text { C } \\
\text { C }\end{array}$ & & & R & & $\mathbf{R}$ & & & $\begin{array}{l}\text { PM } \\
\text { PM } \\
\text { PM }\end{array}$ & NNI \\
\hline $\begin{array}{l}\mathbf{R} \\
\mathbf{R} \\
\mathbf{R} \\
\mathbf{R} \\
\mathbf{R} \\
\mathbf{R}\end{array}$ & & $\begin{array}{l}\mathrm{R} \\
\mathrm{R} \\
\mathrm{R} \\
\mathrm{R} \\
\mathrm{R} \\
\mathrm{R} \\
\mathrm{R} \\
\mathrm{R} \\
\mathrm{R} \\
\mathrm{R} \\
\mathrm{R} \\
\mathbf{C} \\
\mathrm{R} \\
\mathrm{R} \\
\mathrm{R} \\
\mathrm{R} \\
\mathrm{R} \\
\mathrm{R} \\
\mathbf{C} \\
\mathrm{R} \\
\mathrm{R}\end{array}$ & $\mathbf{R}$ & $\begin{array}{l}\mathbf{R} \\
\mathbf{R} \\
\mathbf{R} \\
\mathbf{C} \\
\mathbf{R} \\
\mathbf{R} \\
\mathbf{R} \\
\mathbf{R} \\
\mathbf{R} \\
\mathbf{R} \\
\mathbf{R} \\
\mathbf{R} \\
\mathbf{R} \\
\mathrm{R}\end{array}$ & & & & & $\begin{array}{l}\text { cf. } \\
\text { R } \\
\text { R } \\
\text { C } \\
\text { R } \\
\text { R } \\
\text { R } \\
\text { R } \\
\text { R } \\
\text { R }\end{array}$ & & $\begin{array}{l}\mathbf{A} \\
\mathbf{C} \\
\mathbf{A} \\
\mathbf{A} \\
\mathbf{C} \\
\mathbf{C} \\
\mathbf{C} \\
\mathbf{C} \\
\mathbf{A} \\
\mathbf{A} \\
\mathbf{A} \\
\mathbf{A} \\
\mathbf{A} \\
\mathbf{A} \\
\mathbf{A} \\
\mathbf{A} \\
\mathbf{C} \\
\mathbf{C} \\
\mathbf{A} \\
\mathbf{A} \\
\mathbf{A} \\
\mathbf{A} \\
\mathbf{C} \\
\mathbf{C} \\
\mathbf{C}\end{array}$ & . & $\begin{array}{l}\text { R } \\
\text { R } \\
\text { R } \\
\text { R } \\
\text { R } \\
\text { R } \\
\text { C } \\
\text { cf. } \\
\text { R } \\
\text { R } \\
\text { R }\end{array}$ & $\begin{array}{l}R \\
R \\
R\end{array}$ & $\begin{array}{l}\text { C } \\
\text { R } \\
R \\
R \\
R \\
R \\
R \\
\text { R } \\
C \\
R \\
C \\
R \\
C \\
C \\
R \\
R \\
R \\
R \\
R\end{array}$ & & & $\begin{array}{l}C \\
C \\
C \\
C \\
C \\
C \\
C \\
A \\
C \\
C \\
C \\
C \\
A \\
C \\
C \\
C \\
C \\
C \\
C \\
C \\
C \\
C \\
C \\
C \\
C\end{array}$ & & & $\begin{array}{l}\mathrm{R} \\
\mathrm{R} \\
\mathrm{R} \\
\mathbf{C} \\
\mathrm{R} \\
\mathrm{R} \\
\mathrm{R} \\
\mathrm{R} \\
\mathrm{R} \\
\mathbf{C} \\
\mathrm{R} \\
\mathbf{C} \\
\mathrm{R} \\
\mathrm{R} \\
\mathrm{R} \\
\mathrm{R} \\
\mathrm{R} \\
\mathrm{R} \\
\text { cf. }\end{array}$ & & $\begin{array}{l}\mathbf{R} \\
\mathbf{R} \\
\mathrm{R} \\
\mathrm{R} \\
\mathrm{R} \\
\mathrm{R}\end{array}$ & $\begin{array}{l}\text { R } \\
R \\
C \\
\\
R \\
R \\
R \\
C \\
R \\
C \\
C \\
C \\
C \\
C \\
C \\
C \\
C \\
R \\
C \\
C \\
R\end{array}$ & $\begin{array}{c}\text { E C } \\
\text { E } \\
\text { E } \\
\text { E } \\
\text { P } \\
\text { E } \\
\text { E } \\
\\
\text { E }\end{array}$ & $\begin{array}{l}\mathrm{PM} \\
\mathrm{PM} \\
\mathrm{PM} \\
\mathrm{PM} \\
\mathrm{PM} \\
\mathrm{PM} \\
\mathrm{PM} \\
\mathrm{PM} \\
\mathrm{PM} \\
\mathrm{PM} \\
\mathrm{PM} \\
\mathrm{PM} \\
\mathrm{PM} \\
\mathrm{PM} \\
\mathrm{M} \\
\mathrm{PM} \\
\mathrm{PM} \\
\mathrm{M} \\
\mathrm{PM} \\
\mathrm{PM} \\
\mathrm{M} \\
\mathrm{P} \\
\mathrm{M} \\
\mathrm{M} \\
\mathrm{M}\end{array}$ & NP25 \\
\hline R & & $\begin{array}{l}R \\
R \\
\end{array}$ & & R & & & & & $\mathbf{R}$ & & $\begin{array}{l}\mathbf{C} \\
\mathbf{C} \\
\mathbf{R}\end{array}$ & & $\begin{array}{l}\mathbf{R} \\
\mathbf{R}\end{array}$ & & & $\begin{array}{l}\mathbf{R} \\
\mathbf{R}\end{array}$ & & $\begin{array}{l}\mathbf{C} \\
\mathbf{C} \\
\mathbf{C}\end{array}$ & $\begin{array}{l}R \\
R\end{array}$ & & & & & $\begin{array}{l}\mathbf{R} \\
\mathbf{C} \\
\mathbf{C}\end{array}$ & $\begin{array}{l}\mathrm{E} \\
\mathrm{E}\end{array}$ & $\begin{array}{l}\mathrm{M} \\
\mathrm{M} \\
\mathrm{P}\end{array}$ & NP24 \\
\hline & cf. & & $\mathbf{R}$ & & $\begin{array}{l}\mathbf{R} \\
\mathbf{R}\end{array}$ & R & $\begin{array}{l}\mathbf{R} \\
\mathbf{R} \\
\mathbf{R}\end{array}$ & & & $\begin{array}{l}\mathrm{R} \\
\mathrm{C} \\
\mathrm{C} \\
\mathrm{C}\end{array}$ & $\begin{array}{l}\mathrm{C} \\
\mathrm{C} \\
\mathrm{C} \\
\mathrm{R}\end{array}$ & & & & & & $\begin{array}{l}\mathbf{R} \\
\mathbf{R}\end{array}$ & $\begin{array}{l}\mathbf{R} \\
\mathbf{R} \\
\mathbf{R} \\
\mathbf{R}\end{array}$ & & $\begin{array}{l}\mathbf{R} \\
\mathbf{R} \\
\mathbf{R} \\
\mathbf{R}\end{array}$ & & $\mathbf{R}$ & & $\begin{array}{l}C \\
C \\
C \\
C\end{array}$ & & $\begin{array}{c}\mathrm{PM} \\
\mathrm{PM} \\
\mathrm{M} \\
\mathrm{M}\end{array}$ & NP15/NP16 \\
\hline
\end{tabular}

ples 592-33-3, 5-6 cm and 592-33-3, $70 \mathrm{~cm}$, excluding at least the middle and upper Oligocene (Zones NP23 to NP25) as well as the lowest Miocene (Zone NN1).

Previous drilling in this area revealed a major hiatus at Site 207, which is close to Site 592 (Fig. 1), with part of the middle Eocene to part of the middle Miocene, representing $\sim 30$ m.y., missing (Edwards, 1973b). A hiatus was noted in Hole 206, also with the upper Eocene to lower middle Oligocene missing ( $\sim 10 \mathrm{~m}$.y.). Hole 206 is close to Sites 589 to 591 , which unfortunately did not reach the corresponding depth to verify a widespread regional unconformity at this level. At Site 208 a hiatus described by Edwards (1973b) is more or less the same as that found at Site 588. In Hole 208 at least part of the middle Eocene (Zone NP16) to the middle Oligocene (Zone NP23) is missing. For a further discussion of the regional unconformities the biostratigraphic synthesis (Martini and Jenkins, this volume) should be consulted.

\section{REMARKS ON SELECTED CALCAREOUS NANNOPLANKTON TAXA}

Most of the Paleogene calcareous nannoplankton taxa found on Leg 90 are well documented elsewhere and need no discussion. Detailed information on calcareous nannoplankton from nearby DSDP legs and New Zealand can be found in Bukry, 1975; Edwards, 1971, 1973a; Edwards and Perch-Nielsen, 1975; Stradner and Edwards, 1968. However, a few taxa that cannot be differentiated by light microscope techniques because of their small size and one new species will be discussed.

Cyclococcolithus sp. In Hole $588 \mathrm{C}$ some small circular forms with the general appearance of the genus Cyclococcolithus as seen with the light microscope were noted in the middle Eocene interval, and are listed as Cyclococcolithus sp. in Table 2.

Discolithina sp. In Holes 592 and 593 a few small and poorly preserved specimens of the genus Discolithina found at various levels are grouped together as Discolithina sp. in Tables 3 and 4, although they actually may represent different species.

Reticulofenestra sp. (small). Under this name all small Reticulofenestra species that cannot be differentiated with the light microscope are grouped together in Tables 2 to 4 .

Sphenolithus sp. In Hole 588C some sphenoliths were found in the middle Eocene interval; they may be related to Sphenolithus radians Deflandre, but were too small to be identified with certainty. They are listed in Table 2 as Sphenolithus sp.

Family SPHENOLITHACEAE Vekshina, 1959 Genus SPHENOLITHUS Deflandre, 1952

Sphenolithus elongatus $\mathbf{n}$. sp.

(Plate 2, Figs. 7, 8)

Holotype. SM.B 13507; Plate 2, Fig. 8.

Description. Basal part constructed of $\sim 9$ regularly placed calcite units (Plate 2, Fig. 7), followed by some irregularly placed smaller cal- 
cite particles, which form a collar from which a solid and prominen spine arises. The spine is clearly visible in normal light, showing maximum relief when parallel to polarizer. In polarized light it has its maximum birefringence with the long axis at $45^{\circ}$ to crossed nicols. With the long axis parallel to crossed nicols only the base shows birefringence.

Size. 6 to $9 \mu \mathrm{m}$.

Remarks. Sphenolithus elongatus new species resembles $S$. heteromorphus Deflandre, but has a distinctly smaller base; the elongated spine is always slender and seems not to vary in size like that in $S$. heteromorphus. Sphenolithus delphix Bukry has longer crystals in the basal part, resulting in a different picture when viewed parallel to crossed nicols (see Martini, 1976, plate 13, figs. 22-24). Note: S. elongatus n. sp. is not listed in Table 2.

Type locality. Sample 588C-7-2, 0-1 cm, upper Oligocene, Zone NP25 (S. ciperoensis Zone).

Distribution. Few in Sample 588C-8-1, 0-1 cm and common in Sample 588C-7-2, 0-1 cm, Lord Howe Rise, upper Oligocene (Zone NP25).

\section{ACKNOWLEDGMENTS}

Thanks are due to the Deutsche Forschungsgemeinschaft (Bonn) for supporting the present study. SEM pictures were taken by J. Tochtenhagen with a Stereoscan Mark 2, which was provided to the Geologisch-Paläontologisches Institut der Universität Frankfurt am Main by the Volkswagenstiftung. My thanks also go to Dr. Stephen J. Percival (MEPSI, Dallas, Texas) and Dr. Sherwood W. Wise (Florida State University, Tallahassee) for reviewing this paper.

The type specimen of the new species and additional material is deposited in the Naturmuseum und Forschungsinstitut Senckenberg, Frankfurt am Main, Germany, Catalog No. SM.B 13507.

\section{REFERENCES}

Bombita, G., and Rusu, A., 1981. New data on the Eocene/Oligocene boundary in the Romanian Carpathians. Palaeogeogr., Palaeoclimatol., Palaeoecol., 36:213-222.

Bukry, D., 1971. Coccolith stratigraphy Leg 6, Deep Sea Drilling Project. In Fisher, A. G., Heezen, B. C., et al., Init. Repts. DSDP, 6: Washington (U.S. Govt. Printing Office), 965-1004.

1973a. Coccolith and silicoflagellate stratigraphy, Tasman Sea and southwestern Pacific Ocean. Deep Sea Drilling Project Leg 21. In Burns, R. E., Andrews, J. E., et al., Init. Repts. DSDP, 21: Washington (U.S. Govt. Printing Office), 885-891.

1973b. Low-latitude coccolith biostratigraphic zonation. In Edgar, N. T., Saunders, J. B., et al., Init. Repts. DSDP, 15: Washington (U.S. Govt. Printing Office), 685-703.

, 1975. Silicoflagellate and coccolith stratigraphy, Deep Sea Drilling Project, Leg 29. In Kennett, J. P., Houtz, R. E., et al., Init. Repts. DSDP, 29: Washington (U.S. Govt. Printing Office), 845-872.

Edwards, A. R., 1971. A calcareous nannoplankton zonation of the New Zealand Paleogene. In Farinacci, A. (Ed.), Proc. II Planktonic Conf., Roma, 1970 (Vol. 1): Rome (Edizioni Tecnoscienza), 381-419.

1973a. Calcareous nannofossils from the Southwest Pacific, Deep Sea Drilling Project, Leg 21. In Burns, R. E., Andrews, J. E., et al., Init. Repts. DSDP, 21: Washington (U.S. Govt. Printing Office), 641-691.

1973b. Southwest Pacific regional unconformities encountered during Leg 21. In Burns, R. E., Andrews J. E., et al., Init. Repts. DSDP, 21: Washington (U.S. Govt. Printing Office), 701-720.

Edwards, A. R., and Perch-Nielsen, K., 1975. Calcareous nannofossils from the southern southwest Pacific, Deep Sea Drilling Project, Leg 29. In Kennett, J. P., Houtz, R. E., et al., Init. Repts. DSDP, 29: Washington (U.S. Govt. Printing Office), 469-539.

Hardenbol, J., and Berggren, W. A., 1978. A new Paleogene numeric timescale. In Cohee, G. V., Glaessner, M. F., and Hedberg, H. D. (Eds.), Contributions to the Geologic Time Scale. Am. Assoc. Pet. Geol. Stud. Geol., 6:213-234.

Harland, W. B., Cox, A. V., Llewellyn, P. G., Pickton, C. A. G., Smith, A. G., and Walters, R., 1982. A Geologic Time Scale. Cambridge Earth Science Series.

Martini, E., 1971. Standard Tertiary and Quaternary calcareous nannoplankton zonation. Proc. II Planktonic Conf., Roma 1970 (Vol. 2): Rome (Edizioni Tecnoscienza), 739-785.
1976. Cretaceous to Recent calcareous nannoplankton from the central Pacific Ocean (DSDP Leg 33). In Schlanger, S. O., Jackson, E. D., et al., Init. Repts. DSDP, 33: Washington (U.S. Govt. Printing Office), 383-423.

1979. Calcareous nannoplankton and silicoflagellate biostratigraphy at Reykjanes Ridge, northeastern North Atlantic (DSDP Leg 49, Sites 407 and 409). In Luyendyk, B. P., Cann, J. R., et al., Init. Repts. DSDP, 49: Washington (U.S. Govt. Printing Office), 533-549.

1980. Oligocene to Recent calcareous nannoplankton from the Philippine Sea, Deep Sea Drilling Project Leg 59. In Kroenke, L., Scott, R., et al., Init. Repts. DSDP, 59: Washington (U.S. Govt. Printing Office), 547-567.

1981a. Nannoplankton in der Ober-Kreide, im Alttertiär und im tieferen Jungtertiär von Süddeutschland und dem angrenzenden Österreich. Geol. Bavarica, 82:345-356.

1981b. Upper Eocene and Lower Oligocene calcareous nannoplankton from the Fore-Sudetic monocline. Bull. Acad. Polon. Sci., 29:45-50.

Müller, C., 1976. Tertiary and Quaternary calcareous nannoplankton in the Norwegian-Greenland Sea, DSDP, Leg 38. In Talwani, M., Udintsev, G., et al., Init. Repts. DSDP, 38: Washington (U.S. Govt. Printing Office), 823-841.

1978. Remarks on biostratigraphically useful nannofossils in the Paleogene of the northern hemisphere. Strat. Newsl., 7:45-52.

1981. Calcareous nannoplankton and silicoflagellates. In Cati, F. (Ed.), In Search of the Paleogene/Neogene Boundary Stratotype. Part 1: Potential Boundary Stratotype Sections in Italy and Greece and a Comparison with Results from the Deep Sea. Giorn. Geol. Ser. 2a, 44:33-38.

Snyder, S. W., Müller, C., and Mille, K. G., 1984. Eocene-Oligocene boundary: Biostratigraphic recognition and gradual paleoceanographic change at DSDP Site 549. Geology, 12:112-115.

Srinivasan, M. S., and Kennett, J. P., 1983. The Oligocene-Miocene boundary in the South Pacific. Geol. Soc. Am. Bull., 94:798-812.

Steininger, F. F., 1982. The Palaeogene-Neogene (Oligocene-Miocene) boundary. In Odin, G. S. (Ed.), Numerical Dating in Stratigraphy: New York (John Wiley and Sons), pp. 652-658.

Stradner, H., and Edwards, A. R., 1968. Electron microscope studies on uper Eocene coccoliths from the Oamaru diatomite, New Zealand. Jb. Geol. Bundesanst. Wien, 13:1-66.

Date of Initial Receipt: 12 June 1984

Date of Acceptance: 26 October 1984

\section{APPENDIX \\ Paleogene and Lowest Miocene Calcareous Nannoplankton from the Southwest Pacific}

Blackites spinosus (Deflandre and Fert) Hay and Towe, 1962

B. tenuis (Bramlette and Sullivan) Hay and Mohler, 1967

Braarudosphaera bigelowi (Gran and Braarud) Deflandre, 1947

Campylosphaera dela (Bramlette and Sullivan) Hay and Mohler, 1967

Chiasmolithus altus Bukry and Percival, 1971

C. gigas (Bramlette and Sullivan) Gartner, 1970

C. grandis (Bramlette and Riedel) Radomski, 1968

C. oamaruensis (Deflandre) Hay, Mohler and Wade, 1966

C. solitus (Bramlette and Sullivan) Locker, 1968

Chiphragmalithus alatus (Martini) Martini, 1969

Coccolithus abisectus Müller, 1970

C. eopelagicus (Bramlette and Riedel) Bramlette and Sullivan, 1961

C. miopelagicus Bukry, 1971

C. pelagicus (Wallich) Schiller, 1930

Corannulus germanicus Stradner, 1962

Coronocyclus nitescens (Kamptner) Bramlette and Wilcoxon, 1967

Cribrocentrum reticulatum (Gartner and Smith) Perch-Nielsen, 1971

Cyclococcolithus floridanus (Roth and Hay) Müller, 1970

C. formosus Kamptner, 1963

Cyclococcolithus sp.

Dictyococcites dictyodus (Deflandre and Fert) Martini, 1969

D. aff. dictyodus (Deflandre and Fert) Martini, 1969

Discoaster barbadiensis Tan Sin Hok, 1927

D. binodosus Martini, 1958

D. deflandrei Bramlette and Riedel, 1954

D. druggii Bramlette and Wilcoxon, 1967

D. germanicus Martini, 1958 
D. lenticularis Bramlette and Sullivan, 1961

D. saipanensis Bramlette and Riedel, 1954

D. tani Bramlette and Riedel, 1954

D. wemmelensis Achutan and Stradner, 1969

Discolithina desueta Müller, 1970

D. distincta (Bramlette and Sullivan) Levin and Joerger, 1967

D. enormis Locker, 1967

D. punctosa (Bramlette and Sullivan) Perch-Nielsen, 1971

Discolithina sp.

Ericsonia fenestrata (Deflandre and Fert) Stradner, 1968

E. subdisticha (Roth and Hay) Roth, 1969

Helicosphaera carteri (Wallich) Kamptner, 1964

H. compacta Bramlette and Wilcoxon, 1967

H. dinesenii (Perch-Nielsen) Jafar and Martini, 1975

H. euphratis Haq, 1966

H. granulata (Bukry and Percival) Jafar and Martini, 1975

H. intermedia Martini, 1965

$H$. recta (Haq) Jafar and Martini, 1975

H. seminulum (Bramlette and Sullivan) Jafar and Martini, 1975

Isthmolithus recurvus Deflandre, 1954

Lanternithus minutus Stradner, 1962

Markalius inversus (Deflandre) Bramlette and Martini, 1964

Neococcolithes dubius (Deflandre) Black, 1967
Orthorhabdus serratus Bramlette and Wilcoxon, 1967

Orthozygus aureus (Stradner) Bramlette and Wilcoxon, 1967

Reticulofenestra insignita Roth and Hay, 1967

$R$. oamaruensis (Deflandre) Stradner and Edwards, 1968

R. pseudoumbilica (Gartner) Gartner, 1969

R. umbilica (Levin) Martini and Ritzkowski, 1968

$R$. sp. (small)

Sphenolithus capricornutus Bukry and Percival, 1971

S. ciperoensis Bramlette and Wilcoxon, 1967

S. delphix Bukry, 1973

S. dissimilis Bukry and Percival, 1971

S. distentus (Martini) Bramlette and Wilcoxon, 1967

S. elongatus Martini, new species

S. furcatolithoides Locker, 1967

S. moriformis (Brönnimann and Stradner) Bramlette and Wilcoxon, 1967

S. predistentus Bramlette and Wilcoxon, 1967

S. sp.

Transversopontis pulcheroides (Sullivan) Perch-Nielsen, 1971

Triquetrorhabdulus carinatus Martini, 1965

T. inversus Bukry and Bramlette, 1969

T. milowii Bukry, 1971

Zygrhablithus bijugatus (Deflandre) Deflandre, 1959 


\section{E. MARTINI}

Table 3. Distribution of calcareous nannoplankton in selected samples from Hole 592 and identification of standard nannoplankton zones.

\begin{tabular}{|c|c|c|c|c|c|c|c|c|c|c|c|c|c|c|c|c|c|c|c|c|c|c|c|}
\hline $\begin{array}{l}\text { Core-Section } \\
\text { (interval in cm) }\end{array}$ & 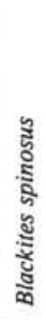 & 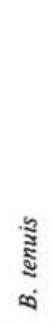 & 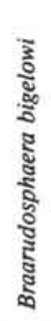 & 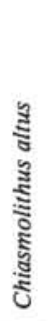 & 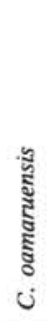 & 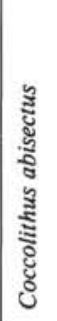 & 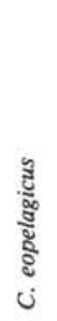 & 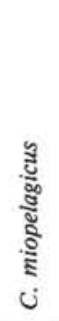 & 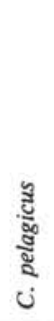 & 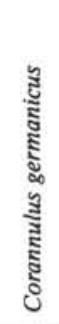 & 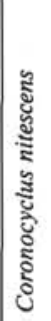 & 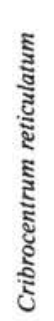 & 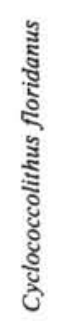 & 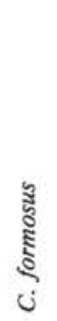 & 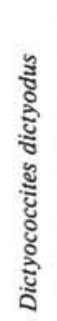 & 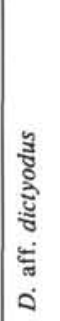 & 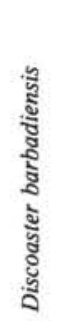 & 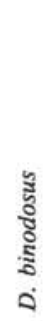 & 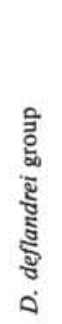 & $\begin{array}{l}: \\
0 \\
\text { है } \\
\text { है } \\
\dot{0}\end{array}$ & $\begin{array}{l}\text { है } \\
\text { हूँ } \\
\text { हैं } \\
\dot{0}\end{array}$ & $\frac{\tilde{E}}{\dot{\Xi}}$ & 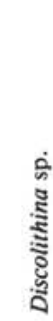 \\
\hline $\begin{array}{l}32, \mathrm{CC} \\
33-1,5-6 \\
33-3,5-6\end{array}$ & & & & & & $\begin{array}{l}\mathrm{R} \\
\mathrm{R} \\
\mathrm{C}\end{array}$ & & $\begin{array}{l}\mathrm{R} \\
\mathrm{C} \\
\mathrm{C}\end{array}$ & $\begin{array}{l}\text { C } \\
\text { C } \\
\text { C }\end{array}$ & & $\begin{array}{l}\mathrm{R} \\
\mathrm{R} \\
\mathrm{R}\end{array}$ & & $\begin{array}{l}\mathbf{C} \\
\mathbf{A} \\
\mathbf{A}\end{array}$ & & & & & & $\begin{array}{l}\mathbf{A} \\
\mathbf{A} \\
\mathbf{C}\end{array}$ & $\begin{array}{l}\text { cf. } \\
\text { cf. } \\
\text { cf. }\end{array}$ & & & $\mathbf{R}$ \\
\hline $\begin{array}{l}33-3,70 \\
33-4,5-6 \\
33, \mathrm{CC} \\
34-3,3-4 \\
34, \mathrm{CC}\end{array}$ & R & $\begin{array}{l}\mathrm{R} \\
\mathrm{R} \\
\mathrm{C} \\
\mathrm{C} \\
\mathrm{C}\end{array}$ & $\begin{array}{l}\mathrm{R} \\
\mathrm{R}\end{array}$ & $\begin{array}{l}\mathrm{C} \\
\mathrm{C} \\
\mathrm{C} \\
\mathrm{C} \\
\mathrm{C}\end{array}$ & $\begin{array}{l}\mathrm{R} \\
\mathrm{R} \\
\mathrm{R} \\
\mathrm{R} \\
\mathrm{C}\end{array}$ & & $\begin{array}{l}\mathrm{R} \\
\mathrm{R} \\
\mathrm{C} \\
\mathrm{C} \\
\mathrm{R}\end{array}$ & & $\begin{array}{l}\text { C } \\
\text { C } \\
\text { C } \\
\text { C } \\
\text { C }\end{array}$ & & R & & $\begin{array}{l}\text { C } \\
\text { C } \\
\text { C } \\
\text { C } \\
\text { C }\end{array}$ & & $\begin{array}{l}\mathbf{A} \\
\mathbf{A} \\
\mathbf{A} \\
\mathbf{A} \\
\mathbf{C}\end{array}$ & $\begin{array}{l}\mathrm{R} \\
\mathrm{R} \\
\mathrm{R} \\
\mathrm{R}\end{array}$ & & $\mathrm{R}$ & $\begin{array}{l}\mathrm{R} \\
\mathrm{R} \\
\mathrm{R}\end{array}$ & & & $\begin{array}{l}\mathrm{R} \\
\mathrm{R} \\
\mathrm{R} \\
\mathrm{R} \\
\mathrm{R}\end{array}$ & $\mathbf{R}$ \\
\hline $\begin{array}{l}35-1,3-4 \\
35-5,3-4 \\
35, \mathrm{CC} \\
36-1,3-4 \\
36-3,3-4 \\
36, \mathrm{CC} \\
37-1,4-5 \\
37-1,5-6\end{array}$ & $\mathbf{R}$ & $\begin{array}{l}\mathrm{C} \\
\mathrm{C} \\
\mathrm{C} \\
\mathrm{R} \\
\mathrm{R} \\
\mathrm{R} \\
\mathrm{C} \\
\mathrm{C}\end{array}$ & & $\begin{array}{l}\text { A } \\
\text { A } \\
\text { C } \\
\text { C } \\
\text { C } \\
\text { R } \\
\text { R } \\
\text { C }\end{array}$ & $\begin{array}{l}\text { C } \\
\text { C } \\
\text { C } \\
\text { R } \\
\text { C } \\
\text { C } \\
\text { C } \\
\text { C }\end{array}$ & & $\begin{array}{l}\mathrm{R} \\
\mathrm{C} \\
\mathrm{R} \\
\mathrm{R} \\
\mathrm{C} \\
\mathrm{R} \\
\mathrm{R} \\
\mathrm{R}\end{array}$ & & $\begin{array}{l}\text { C } \\
\text { C } \\
\text { C } \\
\text { C } \\
\text { C } \\
\text { C } \\
\text { C } \\
\text { A }\end{array}$ & & $\mathbf{R}$ & & $\begin{array}{l}\text { C } \\
\text { C } \\
\text { C } \\
\text { C } \\
\text { C } \\
\text { C } \\
\text { C } \\
\text { C }\end{array}$ & $\begin{array}{l}\mathrm{R} \\
\mathrm{R} \\
\mathrm{R} \\
\mathrm{R} \\
\mathrm{R} \\
\mathrm{C} \\
\mathrm{C} \\
\mathrm{R}\end{array}$ & $\begin{array}{l}\mathbf{A} \\
\mathbf{A} \\
\mathbf{A} \\
\mathbf{A} \\
\mathbf{A} \\
\mathbf{A} \\
\mathbf{A} \\
\mathbf{A}\end{array}$ & $\begin{array}{l}\mathrm{R} \\
\mathrm{R} \\
\mathrm{R} \\
\mathrm{R} \\
\mathrm{R} \\
\mathrm{R} \\
\mathrm{R}\end{array}$ & & & & & & $\begin{array}{l}\mathrm{R} \\
\mathrm{R} \\
\mathrm{R} \\
\mathrm{R} \\
\mathrm{R} \\
\mathrm{R} \\
\mathrm{R} \\
\mathrm{R}\end{array}$ & R \\
\hline $\begin{array}{l}37-2,33-34 \\
37-2,93-94 \\
37-4,4-5 \\
37, C^{*} \\
38-2,3-4 \\
38-4,3-4 \\
38, C C \\
39-1,3-4 \\
39, C C \\
40-3,3-4 \\
40-4,3-4 \\
40, C C \\
41-1,3-4 \\
41-4,3-4 \\
41, C^{*}\end{array}$ & & $\begin{array}{l}\text { C } \\
\text { C } \\
\text { R } \\
\text { R } \\
\text { R } \\
\text { R } \\
\text { R } \\
\text { R } \\
R \\
R \\
R \\
R \\
R \\
R \\
R\end{array}$ & $\mathbf{R}$ & $\begin{array}{l}\text { C } \\
\text { C } \\
\text { R } \\
\text { R }\end{array}$ & $\begin{array}{l}\mathrm{R} \\
\mathrm{R} \\
\mathrm{R} \\
\mathrm{R} \\
\mathrm{C} \\
\mathrm{R} \\
\mathrm{R} \\
\mathrm{C}\end{array}$ & & $\begin{array}{l}\mathrm{R} \\
\mathrm{R} \\
\mathrm{R} \\
\mathrm{R} \\
\mathrm{R} \\
\mathrm{R} \\
\mathrm{R} \\
\mathrm{R} \\
\mathrm{R} \\
\mathrm{C} \\
\mathrm{C} \\
\mathrm{R} \\
\mathrm{R} \\
\mathrm{R} \\
\mathrm{R}\end{array}$ & & $\begin{array}{l}\text { C } \\
\text { C } \\
\text { C } \\
\text { C } \\
\text { C } \\
\text { C } \\
\text { C } \\
\text { C } \\
\text { C } \\
\text { C } \\
\text { C } \\
\text { C } \\
\text { C } \\
\text { C } \\
\text { C }\end{array}$ & $\begin{array}{l}\mathrm{C} \\
\mathrm{R}\end{array}$ & $\mathbf{R}$ & $\begin{array}{l}\mathrm{R} \\
\mathrm{C} \\
\mathrm{C} \\
\mathrm{C} \\
\mathrm{C} \\
\mathrm{C} \\
\mathrm{C}\end{array}$ & $\begin{array}{l}\mathrm{C} \\
\mathrm{R} \\
\mathrm{C} \\
\mathrm{C} \\
\mathrm{C} \\
\mathrm{C} \\
\mathrm{C} \\
\mathrm{C} \\
\mathrm{C} \\
\mathrm{C} \\
\mathrm{C} \\
\mathrm{C} \\
\mathrm{C} \\
\mathrm{C} \\
\mathrm{C}\end{array}$ & $\begin{array}{l}\mathrm{R} \\
\mathrm{R} \\
\mathrm{R} \\
\mathrm{R} \\
\mathrm{R} \\
\mathrm{R} \\
\mathrm{R} \\
\mathrm{R} \\
\mathrm{R} \\
\mathrm{C} \\
\mathrm{R} \\
\mathrm{R} \\
\mathrm{R} \\
\mathrm{R} \\
\mathrm{R}\end{array}$ & $\begin{array}{l}\mathbf{A} \\
\mathbf{A} \\
\mathbf{A} \\
\mathbf{A} \\
\mathbf{A} \\
\mathbf{A} \\
\mathbf{A} \\
\mathbf{A} \\
\mathbf{A} \\
\mathbf{A} \\
\mathbf{A} \\
\mathbf{A} \\
\mathbf{A} \\
\mathbf{C} \\
\mathbf{C}\end{array}$ & $\begin{array}{l}\mathrm{R} \\
\mathrm{R} \\
\mathrm{R} \\
\mathrm{R} \\
\mathrm{R} \\
\mathrm{R} \\
\mathrm{R} \\
\mathrm{R} \\
\mathrm{R} \\
\mathrm{R} \\
\mathrm{R} \\
\mathrm{R} \\
\mathrm{R}\end{array}$ & $\begin{array}{l}\mathrm{R} \\
\mathrm{R}\end{array}$ & R & & & $\begin{array}{l}\mathrm{R} \\
\mathrm{R} \\
\mathrm{R} \\
\mathrm{R} \\
\mathrm{R} \\
\mathrm{R} \\
\mathrm{R} \\
\mathrm{R} \\
\mathrm{C} \\
\mathrm{C} \\
\mathrm{R} \\
\mathrm{R} \\
\mathrm{R} \\
\mathrm{R} \\
\mathrm{R}\end{array}$ & $\begin{array}{l}\mathrm{R} \\
\mathrm{R} \\
\mathrm{R} \\
\mathrm{R} \\
\mathrm{R} \\
\mathrm{R} \\
\mathrm{R} \\
\\
\mathrm{R} \\
\mathrm{C} \\
\mathrm{R} \\
\mathrm{R} \\
\mathrm{R} \\
\mathrm{R} \\
\mathrm{R}\end{array}$ & \\
\hline
\end{tabular}

Note: $\mathbf{R}=$ rare to few, $\mathbf{C}=$ common, $\mathbf{A}=$ abundant, Preservation: $\mathrm{P}=$ poor, $\mathbf{M}=$ moderate, $\mathrm{G}=$ good. Reworking: $\mathrm{E}=$ Eocene, $\mathrm{O}=\mathrm{Oligocene}{ }^{*}=$ samples studied with scanning electron microscope. 
Table 3. (Continued).

\begin{tabular}{|c|c|c|c|c|c|c|c|c|c|c|c|c|c|c|c|c|c|c|c|c|c|c|}
\hline 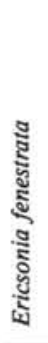 & 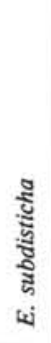 & 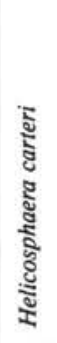 & 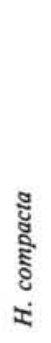 & 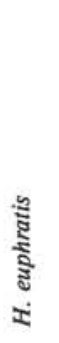 & 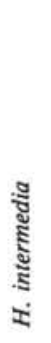 & 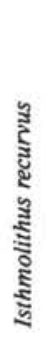 & 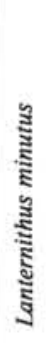 & 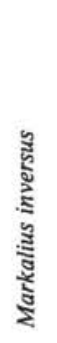 & 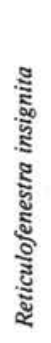 & 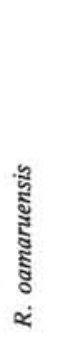 & 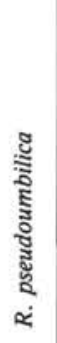 & 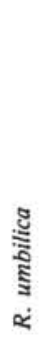 & 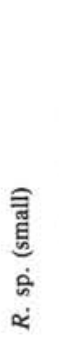 & 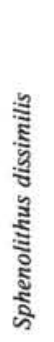 & 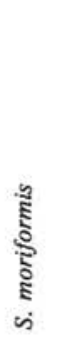 & 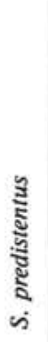 & 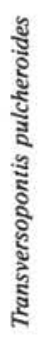 & 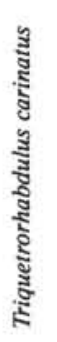 & 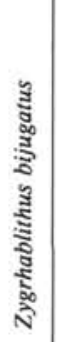 & 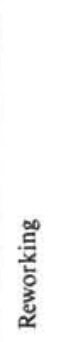 & 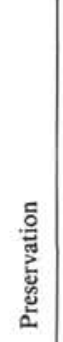 & $\begin{array}{c}\text { Standard } \\
\text { nannoplankton } \\
\text { zones }\end{array}$ \\
\hline & & $\begin{array}{c}\text { R } \\
\text { cf. }\end{array}$ & & $\begin{array}{l}\mathrm{R} \\
\mathrm{R}\end{array}$ & & & & & & & $\begin{array}{l}\mathrm{C} \\
\mathrm{R} \\
\mathrm{R} \\
\end{array}$ & & $\begin{array}{l}\mathbf{C} \\
\mathbf{A} \\
\mathbf{A}\end{array}$ & $\begin{array}{l}\mathrm{R} \\
\mathrm{R} \\
\mathrm{R}\end{array}$ & $\begin{array}{l}\mathbf{C} \\
\mathbf{C} \\
\mathbf{C}\end{array}$ & & & $\begin{array}{l}\mathrm{R} \\
\mathrm{R} \\
\mathrm{R} \\
\end{array}$ & & $\begin{array}{l}\text { EO } \\
\text { EO } \\
\text { EO } \\
\end{array}$ & $\begin{array}{l}\mathrm{PM} \\
\mathrm{PM} \\
\mathrm{PM}\end{array}$ & NN2 \\
\hline $\begin{array}{l}\mathrm{C} \\
\mathrm{R} \\
\mathrm{C}\end{array}$ & $\begin{array}{l}\text { C } \\
\text { C } \\
\text { C }\end{array}$ & & & & R & $\begin{array}{l}\mathbf{R} \\
\mathbf{R} \\
\mathbf{R} \\
\mathbf{C}\end{array}$ & $\begin{array}{l}\mathrm{R} \\
\mathrm{R} \\
\mathrm{C} \\
\mathrm{C} \\
\mathrm{C}\end{array}$ & $\mathbf{R}$ & $\begin{array}{l}\mathrm{R} \\
\mathrm{C} \\
\mathrm{C} \\
\mathrm{R} \\
\mathrm{C}\end{array}$ & & & $\begin{array}{l}\text { C } \\
\text { R } \\
\text { C } \\
\text { C } \\
\text { A }\end{array}$ & $\begin{array}{l}\mathbf{C} \\
\mathbf{C} \\
\mathbf{C} \\
\mathbf{C} \\
\mathbf{C}\end{array}$ & & $\begin{array}{l}\mathbf{R} \\
\mathbf{R} \\
\mathbf{C} \\
\mathrm{C} \\
\mathrm{C}\end{array}$ & R & $\mathrm{R}$ & & $\begin{array}{l}\mathbf{R} \\
\mathbf{R} \\
\mathbf{C} \\
\mathbf{A} \\
\mathbf{C}\end{array}$ & & $\begin{array}{c}\mathrm{PM} \\
\mathrm{M} \\
\mathrm{M} \\
\mathrm{M} \\
\mathrm{M}\end{array}$ & NP22 \\
\hline $\mathbf{R}$ & $\begin{array}{l}\text { C } \\
R \\
R \\
R \\
R \\
R \\
R \\
R\end{array}$ & & $\begin{array}{l}\mathrm{R} \\
\mathrm{R} \\
\mathrm{R} \\
\mathrm{R}\end{array}$ & & $\mathbf{R}$ & $\begin{array}{l}\mathrm{C} \\
\mathrm{R} \\
\mathrm{C} \\
\mathrm{C} \\
\mathrm{C} \\
\mathrm{C} \\
\mathrm{C} \\
\mathrm{C}\end{array}$ & $\begin{array}{l}\mathbf{R} \\
\mathbf{R} \\
\mathbf{R} \\
\mathbf{R}\end{array}$ & $\begin{array}{l}\mathrm{R} \\
\mathrm{R} \\
\mathrm{R}\end{array}$ & $\begin{array}{l}\text { C } \\
\mathbf{C} \\
\mathbf{A} \\
\mathbf{C} \\
\mathbf{C} \\
\mathbf{C} \\
\mathbf{C} \\
\mathbf{C}\end{array}$ & $\begin{array}{l}\mathrm{R} \\
\mathrm{R} \\
\mathrm{R} \\
\mathrm{R} \\
\mathrm{R} \\
\mathrm{R}\end{array}$ & & $\begin{array}{l}\mathbf{A} \\
\mathbf{A} \\
\mathbf{A} \\
\mathbf{C} \\
\mathbf{C} \\
\mathbf{A} \\
\mathbf{C} \\
\mathbf{A}\end{array}$ & $\begin{array}{l}\text { C } \\
\text { C } \\
\text { C } \\
\text { C } \\
\text { C } \\
\text { C } \\
\text { C } \\
\text { A }\end{array}$ & & $\begin{array}{l}\text { R } \\
\text { R } \\
\text { R } \\
\text { R } \\
\text { R } \\
\text { R } \\
\text { R } \\
\text { R }\end{array}$ & $\mathbf{R}$ & $\begin{array}{l}\mathbf{R} \\
\mathrm{R} \\
\mathrm{R}\end{array}$ & & $\begin{array}{l}\mathbf{C} \\
\mathbf{A} \\
\mathbf{A} \\
\mathbf{C} \\
\mathbf{A} \\
\mathbf{A} \\
\mathbf{A} \\
\mathbf{A}\end{array}$ & & $\begin{array}{l}\mathrm{M} \\
\mathrm{M} \\
\mathrm{M} \\
\mathrm{M} \\
\mathrm{M} \\
\mathrm{M} \\
\mathrm{M} \\
\mathrm{M}\end{array}$ & NP21 \\
\hline $\mathbf{R}$ & $\mathbf{R}$ & & $\begin{array}{l}\mathbf{R} \\
\mathbf{R}\end{array}$ & & $\mathbf{R}$ & $\begin{array}{l}\text { C } \\
C \\
\text { R } \\
C \\
\text { R } \\
\text { R } \\
\text { R } \\
C \\
C \\
\text { R } \\
\text { R }\end{array}$ & $\begin{array}{l}\mathrm{R} \\
\mathrm{R} \\
\mathrm{R} \\
\mathrm{R} \\
\mathrm{R} \\
\mathrm{R} \\
\mathrm{R} \\
\mathrm{R} \\
\mathrm{R} \\
\mathrm{C} \\
\mathrm{R}\end{array}$ & $\begin{array}{l}\text { R } \\
\text { R } \\
\text { R } \\
\text { R } \\
\text { R } \\
\text { R } \\
\text { R } \\
\text { R } \\
\text { R }\end{array}$ & $\begin{array}{l}\text { C } \\
\text { C } \\
\text { C } \\
\text { C } \\
\text { C } \\
\text { C } \\
\text { R } \\
\text { R } \\
\\
\text { R } \\
\text { R }\end{array}$ & $\begin{array}{l}\mathrm{R} \\
\mathrm{R} \\
\mathrm{R}\end{array}$ & & $\begin{array}{l}\mathbf{A} \\
\mathbf{A} \\
\mathbf{A} \\
\mathbf{A} \\
\mathbf{A} \\
\mathbf{A} \\
\mathbf{A} \\
\mathbf{C} \\
\mathbf{C} \\
\mathbf{A} \\
\mathbf{A} \\
\mathbf{A} \\
\mathbf{A} \\
\mathbf{A} \\
\mathbf{A}\end{array}$ & $\begin{array}{l}\mathbf{C} \\
\mathbf{C} \\
\mathbf{C} \\
\mathbf{C} \\
\mathbf{C} \\
\mathbf{C} \\
\mathbf{A} \\
\mathbf{A} \\
\mathbf{C} \\
\mathbf{C} \\
\mathbf{C} \\
\mathbf{C} \\
\mathbf{C} \\
\mathbf{C} \\
\mathbf{C}\end{array}$ & & $\begin{array}{l}\mathrm{R} \\
\mathrm{R} \\
\mathrm{R} \\
\mathrm{R} \\
\mathrm{R} \\
\mathrm{R} \\
\mathrm{R} \\
\mathrm{C} \\
\mathrm{R} \\
\mathrm{R} \\
\mathrm{R} \\
\mathrm{R} \\
\mathrm{R} \\
\mathrm{R} \\
\mathrm{R}\end{array}$ & & $\begin{array}{l}\mathbf{R} \\
\mathrm{R} \\
\mathrm{R} \\
\mathrm{R}\end{array}$ & & $\begin{array}{l}\mathbf{A} \\
\mathbf{C} \\
\mathbf{A} \\
\mathbf{A} \\
\mathbf{C} \\
\mathbf{A} \\
\mathbf{C} \\
\mathbf{C} \\
\mathbf{A} \\
\mathbf{C} \\
\mathbf{C} \\
\mathbf{A} \\
\mathbf{C} \\
\mathbf{R} \\
\mathbf{A}\end{array}$ & $\begin{array}{l}\mathrm{E} \\
\mathrm{E} \\
\mathrm{E} \\
\mathrm{E}\end{array}$ & $\begin{array}{l}\mathrm{M} \\
\mathrm{M} \\
\mathrm{M} \\
\mathrm{M} \\
\mathrm{M} \\
\mathrm{M} \\
\mathrm{M} \\
\mathrm{M} \\
\mathrm{M} \\
\mathrm{M} \\
\mathrm{M} \\
\mathrm{M} \\
\mathrm{M} \\
\mathrm{M} \\
\mathrm{M}\end{array}$ & NP19/NP20 \\
\hline
\end{tabular}


Table 4. Distribution of calcareous nannoplankton in selected samples from Hole 593 and indication of standard nannoplankton zones.

\begin{tabular}{|c|c|c|c|c|c|c|c|c|c|c|c|c|c|c|c|c|c|c|c|c|c|c|c|c|}
\hline $\begin{array}{l}\text { Core-Section } \\
\text { (interval in cm) }\end{array}$ & 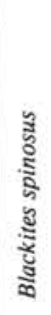 & $\frac{\mathscr{\Xi}}{\mathrm{E}}$ & 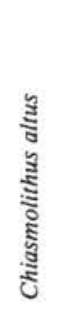 & 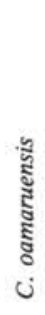 & 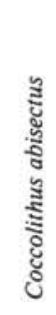 & 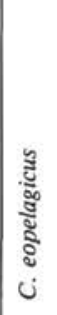 & 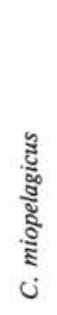 & 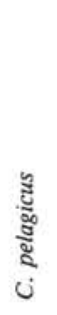 & 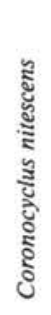 & 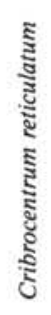 & 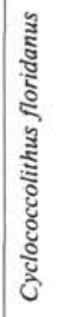 & ن & 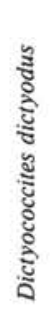 & 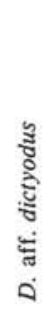 & 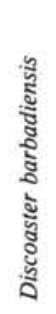 & 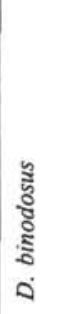 & 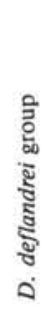 & 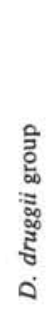 & 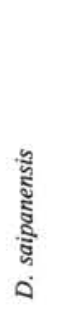 & $\frac{\tilde{E}}{2}$ & 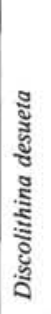 & $\begin{array}{l}\text { ह } \\
\vdots \\
\vdots \\
\vdots\end{array}$ & $\begin{array}{l}\dot{2} \\
\dot{a}\end{array}$ & 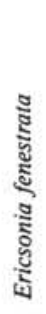 \\
\hline $\begin{array}{l}49, \mathrm{CC} \\
50-1,3-4\end{array}$ & & & & & $\begin{array}{l}\mathbf{C} \\
\mathbf{A}\end{array}$ & & $\begin{array}{l}\mathrm{C} \\
\mathrm{R}\end{array}$ & $\begin{array}{l}\mathbf{C} \\
\mathbf{A}\end{array}$ & & & $\begin{array}{l}\mathbf{A} \\
\mathbf{C}\end{array}$ & & $\mathbf{R}$ & $\mathrm{R}$ & & & $\begin{array}{l}\mathbf{A} \\
\mathbf{A}\end{array}$ & & & & & & & \\
\hline $\begin{array}{l}50-5,3-4 \\
50, C C \\
52-1,3-4 \\
52, C C \\
53-1,3-4 \\
53, C C \\
54-1,3-4 \\
54, C C \\
55-3,3-4\end{array}$ & & $\mathbf{R}$ & $\begin{array}{l}\mathbf{R} \\
\mathbf{C} \\
\mathbf{C} \\
\mathbf{A} \\
\mathbf{A} \\
\mathbf{A} \\
\mathbf{C} \\
\mathbf{A}\end{array}$ & $\begin{array}{l}\mathrm{R} \\
\mathrm{R}\end{array}$ & $\begin{array}{l}\mathrm{R} \\
\mathbf{C} \\
\mathrm{C} \\
\mathrm{R} \\
\mathrm{C} \\
\mathrm{R} \\
\mathbf{A} \\
\mathrm{R} \\
\mathrm{C}\end{array}$ & $\begin{array}{l}\text { cf. } \\
\text { R } \\
\text { R } \\
\text { R } \\
\text { R } \\
\text { R }\end{array}$ & $\begin{array}{l}\mathrm{R} \\
\mathrm{R} \\
\mathrm{R} \\
\mathrm{R} \\
\\
\\
\\
\text { cf. }\end{array}$ & $\begin{array}{l}\text { C } \\
\text { A } \\
\text { C } \\
\text { C } \\
\text { C } \\
\text { C } \\
\text { C } \\
\text { C } \\
\text { C }\end{array}$ & $\begin{array}{l}\mathrm{R} \\
\mathrm{R} \\
\mathrm{C} \\
\mathrm{R}\end{array}$ & & $\begin{array}{l}\mathbf{A} \\
\mathbf{C} \\
\mathbf{C} \\
\mathbf{C} \\
\mathbf{C} \\
\mathbf{A} \\
\mathbf{A} \\
\mathbf{A} \\
\mathbf{C}\end{array}$ & & $\begin{array}{l}\mathbf{R} \\
\mathbf{A} \\
\mathbf{C} \\
\mathbf{C} \\
\mathbf{A} \\
\mathbf{A} \\
\mathbf{A} \\
\mathbf{A} \\
\mathbf{A}\end{array}$ & $\begin{array}{l}\mathrm{R} \\
\mathrm{R} \\
\mathrm{R} \\
\mathrm{R} \\
\mathrm{R} \\
\mathrm{R}\end{array}$ & & & $\begin{array}{l}\mathrm{C} \\
\mathrm{C} \\
\mathrm{C} \\
\mathrm{C}\end{array}$ & cf. & & & $\begin{array}{l}R \\
R \\
R\end{array}$ & cf. & $\mathbf{R}$ & $\begin{array}{l}R \\
\mathrm{R}\end{array}$ \\
\hline $\begin{array}{l}55, \mathrm{CC} \\
56-1,3-4\end{array}$ & & $\begin{array}{l}\mathrm{C} \\
\mathrm{C}\end{array}$ & $\begin{array}{l}\mathrm{C} \\
\mathrm{C}\end{array}$ & $\begin{array}{l}\mathrm{R} \\
\mathrm{R}\end{array}$ & $\begin{array}{l}\text { cf. } \\
\text { cf. }\end{array}$ & R & & $\begin{array}{l}\mathrm{C} \\
\mathrm{C}\end{array}$ & $\begin{array}{l}\mathrm{C} \\
\mathrm{R}\end{array}$ & & $\begin{array}{l}\text { C } \\
\text { C }\end{array}$ & & $\mathbf{A}$ & $\begin{array}{l}\mathrm{R} \\
\mathrm{R}\end{array}$ & & & $\begin{array}{l}\mathrm{R} \\
\mathrm{R}\end{array}$ & & & cf. & & & $\mathbf{R}$ & \\
\hline $\begin{array}{l}56-3,3-4 \\
56, \mathrm{CC} \\
57-1,3-4\end{array}$ & $\mathrm{R}$ & $\begin{array}{l}\mathrm{R} \\
\mathrm{C} \\
\mathrm{C} \\
\end{array}$ & $\begin{array}{l}\mathbf{C} \\
\mathbf{A} \\
\mathbf{A}\end{array}$ & $\begin{array}{l}\mathrm{R} \\
\mathrm{R} \\
\mathrm{C} \\
\end{array}$ & & $\begin{array}{l}\mathrm{R} \\
\mathrm{R} \\
\mathrm{R} \\
\end{array}$ & & $\begin{array}{l}\mathrm{C} \\
\mathrm{C} \\
\mathrm{C} \\
\end{array}$ & $\mathbf{R}$ & & $\begin{array}{l}\mathrm{C} \\
\mathrm{R} \\
\mathrm{R} \\
\end{array}$ & & $\begin{array}{l}\mathbf{A} \\
\mathbf{A} \\
\mathbf{A}\end{array}$ & $\begin{array}{l}\mathrm{R} \\
\mathrm{R} \\
\mathrm{R} \\
\end{array}$ & & & $\mathrm{R}$ & & & & & & & \\
\hline $\begin{array}{l}57-3,3-4 \\
57, \mathrm{CC} \\
58-1,3-4 \\
58-2,5-6 \\
58-2,60-61 \\
58-2,110-111 \\
\end{array}$ & $\mathbf{R}$ & $\begin{array}{l}\mathrm{C} \\
\mathrm{C} \\
\mathrm{R} \\
\mathrm{R} \\
\mathrm{C} \\
\mathrm{C}\end{array}$ & $\begin{array}{l}\mathbf{A} \\
\mathbf{A} \\
\mathbf{C} \\
\mathbf{A} \\
\mathbf{A} \\
\mathbf{A}\end{array}$ & $\begin{array}{l}\mathbf{A} \\
\mathbf{C} \\
\mathbf{C} \\
\mathbf{A} \\
\mathbf{C} \\
\mathbf{C}\end{array}$ & & $\begin{array}{l}\mathrm{R} \\
\mathrm{C} \\
\mathrm{R} \\
\mathrm{C} \\
\mathrm{R} \\
\mathrm{R}\end{array}$ & & $\begin{array}{l}\text { C } \\
\text { C } \\
\text { C } \\
\text { C } \\
\text { C } \\
\text { C }\end{array}$ & $\mathbf{R}$ & & $\begin{array}{l}\mathrm{R} \\
\mathrm{C} \\
\mathrm{C} \\
\mathrm{C} \\
\mathrm{R} \\
\mathrm{C}\end{array}$ & $\begin{array}{l}\mathrm{R} \\
\mathrm{R} \\
\mathrm{R} \\
\mathrm{R} \\
\mathrm{R} \\
\mathrm{R}\end{array}$ & $\begin{array}{l}\mathbf{A} \\
\mathbf{A} \\
\mathbf{A} \\
\mathbf{C} \\
\mathbf{A} \\
\mathbf{A}\end{array}$ & $\begin{array}{l}\mathrm{R} \\
\mathrm{R} \\
\mathrm{R} \\
\mathrm{R} \\
\mathrm{R} \\
\mathrm{R}\end{array}$ & & $\begin{array}{l}\mathrm{R} \\
\mathrm{R} \\
\end{array}$ & 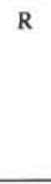 & & & $\begin{array}{l}R \\
R \\
R \\
R \\
R \\
R \\
\end{array}$ & & & & $\begin{array}{l}\mathbf{R} \\
\mathrm{R} \\
\mathrm{R}\end{array}$ \\
\hline $\begin{array}{l}58-3,13 \\
58, C \mathrm{C} \\
59-4,71-72\end{array}$ & & $R$ & $\begin{array}{l}\mathrm{R} \\
\mathrm{R} \\
\mathrm{R}\end{array}$ & $\begin{array}{l}\mathrm{R} \\
\mathrm{R}\end{array}$ & & & & $\begin{array}{l}\mathrm{R} \\
\mathrm{R} \\
\mathrm{R}\end{array}$ & & & $\begin{array}{l}\mathrm{R} \\
\mathrm{R} \\
\mathrm{R}\end{array}$ & $\mathrm{R}$ & $\begin{array}{l}\mathrm{R} \\
\mathrm{R} \\
\mathrm{R}\end{array}$ & & & & & & & $R$ & & & & \\
\hline $\begin{array}{l}59, \mathrm{CC} \\
60-1,6-7 \\
60-3,4-5 \\
60-5,4-6 \\
60-6,63-64 \\
60, \mathrm{CC}^{*}\end{array}$ & $\begin{array}{l}\mathrm{R} \\
\mathrm{R}\end{array}$ & $\begin{array}{l}\mathrm{C} \\
\mathrm{C} \\
\mathrm{C} \\
\mathrm{R} \\
\mathrm{C} \\
\mathrm{C}\end{array}$ & $\begin{array}{l}\mathrm{R} \\
\mathrm{C} \\
\mathrm{C}\end{array}$ & $\begin{array}{l}\mathrm{R} \\
\mathrm{C} \\
\mathrm{R} \\
\mathrm{C} \\
\mathrm{R} \\
\mathrm{C}\end{array}$ & & $\begin{array}{l}\mathrm{R} \\
\mathrm{R} \\
\mathrm{R} \\
\mathrm{R} \\
\mathrm{C} \\
\mathrm{C}\end{array}$ & & $\begin{array}{l}\text { C } \\
\text { C } \\
\text { C } \\
\text { C } \\
\text { A } \\
\text { A }\end{array}$ & $\mathrm{R}$ & $\begin{array}{l}\mathrm{R} \\
\mathrm{R} \\
\mathrm{R} \\
\mathrm{R} \\
\mathrm{R} \\
\mathrm{R}\end{array}$ & $\begin{array}{l}\mathbf{C} \\
\mathbf{A} \\
\mathbf{A} \\
\mathbf{A} \\
\mathbf{A} \\
\mathbf{A}\end{array}$ & R & $\begin{array}{l}\text { C } \\
\text { C } \\
\text { C } \\
\text { C } \\
\text { C } \\
\text { C }\end{array}$ & $\begin{array}{l}\mathrm{R} \\
\mathrm{R} \\
\mathrm{R} \\
\mathrm{R}\end{array}$ & $\begin{array}{l}\mathrm{R} \\
\mathrm{R}\end{array}$ & & & & $\begin{array}{l}\mathrm{R} \\
\mathrm{R} \\
\mathrm{R} \\
\mathrm{R} \\
\mathrm{R}\end{array}$ & $\begin{array}{l}\mathrm{R} \\
\mathrm{R} \\
\mathrm{R}\end{array}$ & & & & \\
\hline
\end{tabular}

Note: $\mathbf{R}=$ rare to few, $\mathbf{C}=$ common, $\mathbf{A}=$ abundant. Preservation: $\mathrm{P}=$ poor, $\mathrm{M}=$ moderate, $\mathrm{G}=$ good. Reworking: $\mathrm{E}=\mathrm{Eocene} .^{*}=$ samples studied with scanning electron microscope. 
Table 4. (Continued).

\begin{tabular}{|c|c|c|c|c|c|c|c|c|c|c|c|c|c|c|c|c|c|c|c|c|c|c|c|c|}
\hline 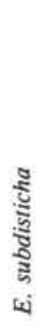 & 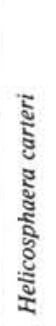 & 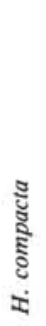 & 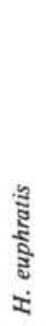 & 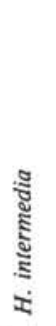 & 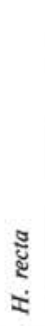 & 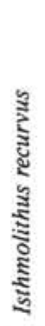 & 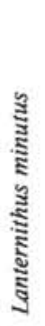 & 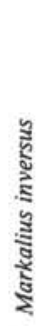 & 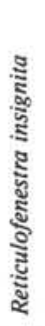 & 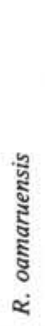 & 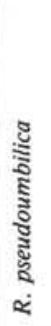 & 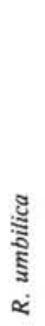 & 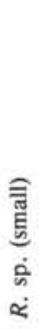 & 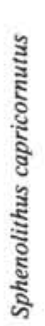 & 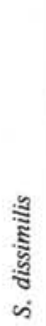 & $\begin{array}{l}\text { है } \\
\text { है } \\
\text { है } \\
\text { is }\end{array}$ & 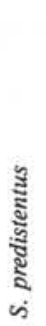 & 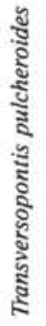 & 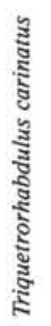 & 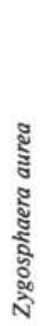 & 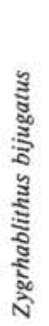 & 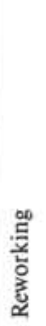 & 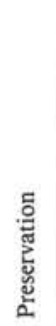 & $\begin{array}{c}\text { Standard } \\
\text { nannoplankton } \\
\text { zones }\end{array}$ \\
\hline & ef. & & & & & & & & & & C & & $\begin{array}{l}\mathbf{A} \\
\mathbf{A}\end{array}$ & $\mathrm{R}$ & $\begin{array}{l}R \\
R\end{array}$ & $\begin{array}{l}\text { C } \\
\text { C }\end{array}$ & & & $\begin{array}{l}\mathrm{R} \\
\mathrm{R}\end{array}$ & & & & $\begin{array}{l}\text { PM } \\
\text { PM }\end{array}$ & NN1 \\
\hline & & $\begin{array}{l}\mathbf{R} \\
\mathbf{R}\end{array}$ & $\begin{array}{l}\mathrm{R} \\
\mathrm{R} \\
\mathrm{R}\end{array}$ & R & R & & & & $\begin{array}{l}\mathrm{R} \\
\mathrm{R} \\
\mathrm{R} \\
\mathrm{C} \\
\mathrm{C} \\
\mathrm{R} \\
\mathrm{C} \\
\mathrm{C}\end{array}$ & & cf. & & $\begin{array}{l}\mathbf{A} \\
\mathbf{A} \\
\mathbf{C} \\
\mathbf{C} \\
\mathbf{A} \\
\mathbf{C} \\
\mathbf{A} \\
\mathbf{A} \\
\mathbf{A}\end{array}$ & 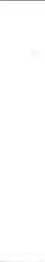 & R & $\begin{array}{l}C \\
C \\
R \\
C \\
R \\
R \\
R \\
R \\
R\end{array}$ & $\begin{array}{l}\mathrm{R} \\
\mathrm{R}\end{array}$ & & $\begin{array}{l}\text { C } \\
\text { R } \\
\text { R } \\
\text { cf. }\end{array}$ & & $\begin{array}{l}\text { R } \\
\text { A } \\
\mathbf{C} \\
\mathbf{C} \\
\mathbf{A} \\
\mathbf{A} \\
\mathbf{A} \\
\mathbf{A} \\
\mathbf{A}\end{array}$ & $\begin{array}{l}\text { E } \\
\\
\\
\text { E } \\
\text { E }\end{array}$ & $\begin{array}{c}\mathrm{PM} \\
\mathrm{PM} \\
\mathrm{PM} \\
\mathrm{PM} \\
\mathrm{M} \\
\mathrm{M} \\
\mathrm{PM} \\
\mathrm{M} \\
\mathrm{M}\end{array}$ & NP24/NP25* \\
\hline & & & & & & & $\begin{array}{l}\mathrm{R} \\
\mathrm{R}\end{array}$ & $\mathbf{R}$ & $\begin{array}{l}R \\
R\end{array}$ & & & & $\begin{array}{l}\mathbf{A} \\
\mathbf{A}\end{array}$ & & & $\begin{array}{l}R \\
C\end{array}$ & R & & & & $\underset{\mathbf{A}}{\mathbf{A}}$ & E & $\begin{array}{l}\mathrm{M} \\
\mathrm{M}\end{array}$ & NP23* \\
\hline $\begin{array}{l}\mathbf{C} \\
\mathbf{A}\end{array}$ & & & & & & $\begin{array}{l}\mathrm{R} \\
\mathrm{R} \\
\mathrm{C}\end{array}$ & $\begin{array}{l}\mathrm{R} \\
\mathbf{C} \\
\mathrm{A}\end{array}$ & & $\begin{array}{l}\mathrm{R} \\
\mathrm{R} \\
\mathrm{R}\end{array}$ & & & $\begin{array}{l}\text { C } \\
\text { A } \\
\text { C }\end{array}$ & $\begin{array}{l}\mathbf{A} \\
\mathbf{A} \\
\mathbf{A}\end{array}$ & & & $\begin{array}{l}\mathrm{R} \\
\mathrm{R} \\
\mathrm{C}\end{array}$ & & & & & $\begin{array}{l}\mathbf{A} \\
\mathbf{A} \\
\mathbf{A}\end{array}$ & & $\begin{array}{l}\mathrm{M} \\
\mathrm{M} \\
\mathrm{M}\end{array}$ & NP22 \\
\hline $\begin{array}{l}\text { A } \\
\text { R } \\
\text { R }\end{array}$ & $\mathrm{R}$ & & & & & $\begin{array}{l}\mathrm{C} \\
\mathrm{C} \\
\mathrm{C} \\
\mathrm{C} \\
\mathrm{C} \\
\mathrm{C}\end{array}$ & A & $\mathrm{R}$ & $\begin{array}{l}\mathbf{C} \\
\mathbf{A} \\
\mathbf{A} \\
\mathbf{A} \\
\mathbf{A} \\
\mathbf{R}\end{array}$ & $\mathrm{R}$ & & $\begin{array}{l}\mathbf{A} \\
\mathbf{A} \\
\mathbf{A} \\
\mathbf{A} \\
\mathbf{A} \\
\mathbf{A}\end{array}$ & $\begin{array}{l}\mathbf{A} \\
\mathbf{A} \\
\mathbf{A} \\
\mathbf{A} \\
\mathbf{A} \\
\mathbf{A}\end{array}$ & & & $\begin{array}{l}R \\
R \\
R \\
R \\
R \\
R\end{array}$ & & cf. & & & $\begin{array}{l}\mathbf{C} \\
\mathbf{A} \\
\mathbf{C} \\
\mathbf{C} \\
\mathbf{A} \\
\mathbf{A}\end{array}$ & & $\begin{array}{l}\mathrm{M} \\
\mathrm{M} \\
\mathrm{M} \\
\mathrm{M} \\
\mathrm{M} \\
\mathrm{M}\end{array}$ & NP21 \\
\hline & & & & & & R & $\mathrm{R}$ & & & $\mathrm{R}$ & & $\begin{array}{l}\mathrm{R} \\
\mathrm{R}\end{array}$ & $\begin{array}{l}R \\
R \\
R\end{array}$ & & & & & & & & $\begin{array}{l}\mathrm{R} \\
\mathrm{R}\end{array}$ & & $\begin{array}{l}\mathrm{PM} \\
\mathrm{M} \\
\mathrm{M}\end{array}$ & $?$ \\
\hline & & & & & & $\begin{array}{c}\mathrm{R} \\
\mathrm{cf}\end{array}$ & $\begin{array}{l}\mathrm{R} \\
\mathrm{R} \\
\mathrm{R} \\
\mathrm{R} \\
\mathbf{C} \\
\mathrm{C}\end{array}$ & $\begin{array}{l}\mathbf{R} \\
\mathbf{R} \\
\mathbf{R}\end{array}$ & R & & & $\begin{array}{l}\mathbf{R} \\
\mathbf{C} \\
\mathbf{A} \\
\mathbf{A} \\
\mathbf{A} \\
\mathbf{A}\end{array}$ & $\begin{array}{l}\mathbf{C} \\
\mathbf{A} \\
\mathbf{A} \\
\mathbf{C} \\
\mathbf{A} \\
\mathbf{A}\end{array}$ & & & $\begin{array}{l}R \\
C \\
R \\
R \\
R \\
R\end{array}$ & & $\begin{array}{c}\mathrm{R} \\
\text { cf. }\end{array}$ & & $R$ & $\begin{array}{l}\text { C } \\
\text { C } \\
\text { C } \\
\text { C } \\
\text { C } \\
\text { C }\end{array}$ & $\begin{array}{l}\mathrm{E} \\
\mathrm{E} \\
\mathrm{E} \\
\mathrm{E} \\
\mathrm{E}\end{array}$ & $\begin{array}{c}\mathrm{M} \\
\mathrm{PM} \\
\mathrm{M} \\
\mathrm{PM} \\
\mathrm{M} \\
\mathrm{M}\end{array}$ & NP19/NP20 \\
\hline
\end{tabular}




\section{E. MARTINI}

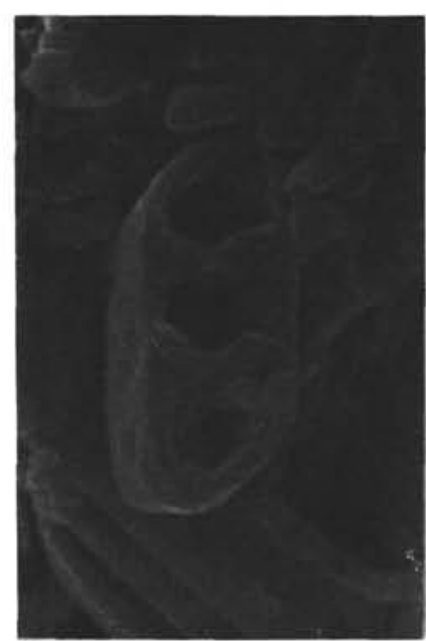

1

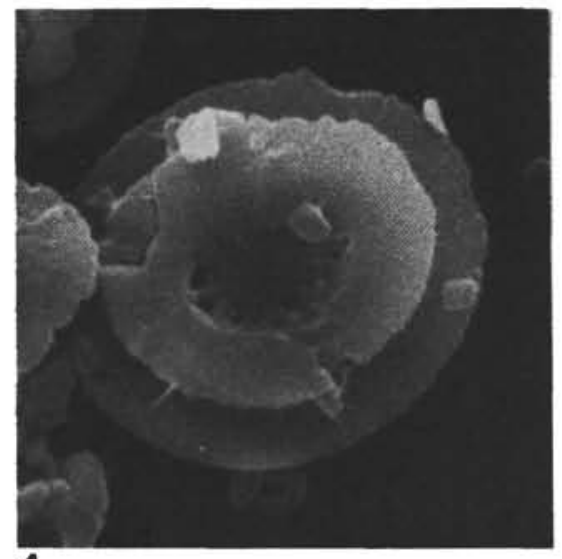

4

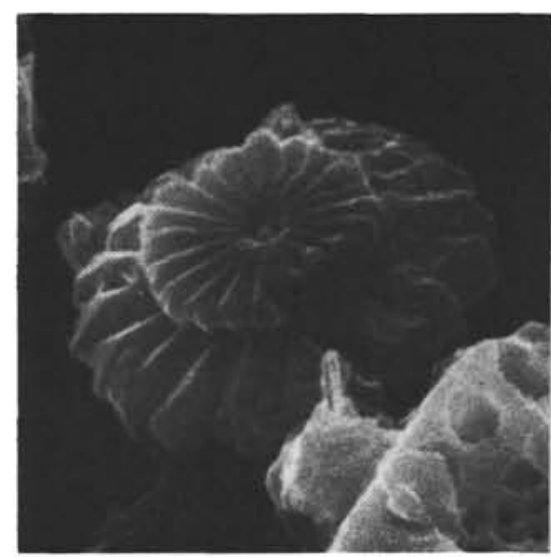

7

2
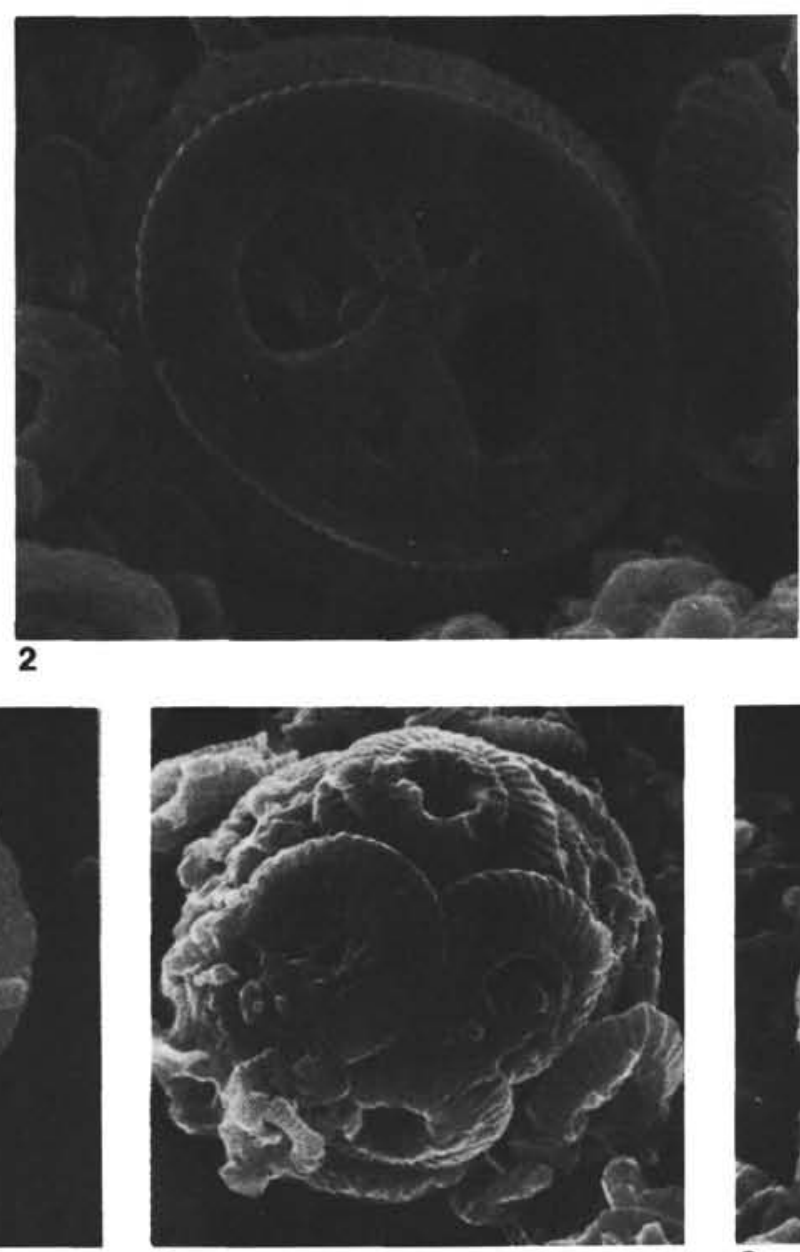

5

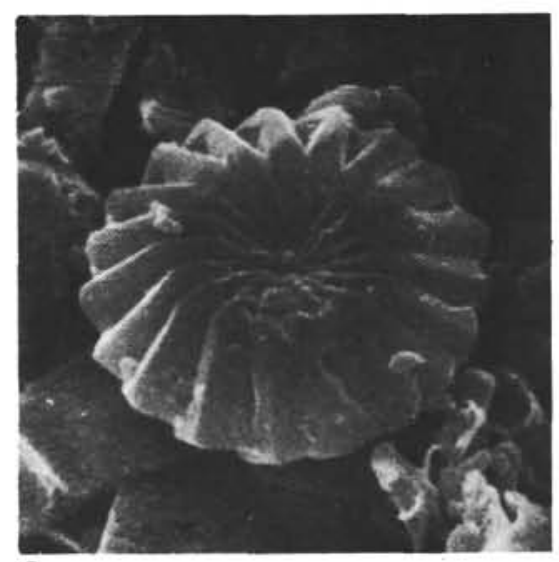

8

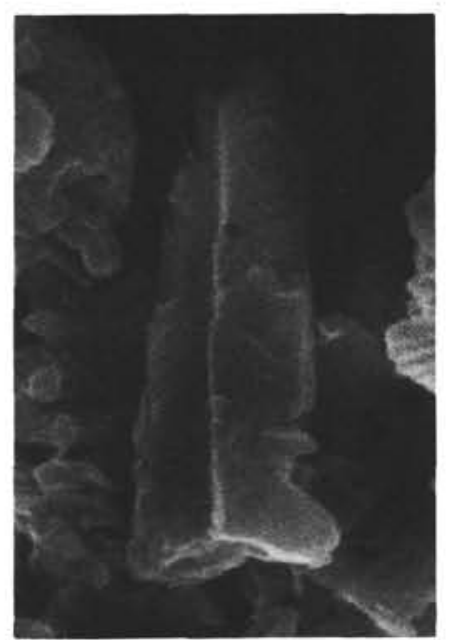

3

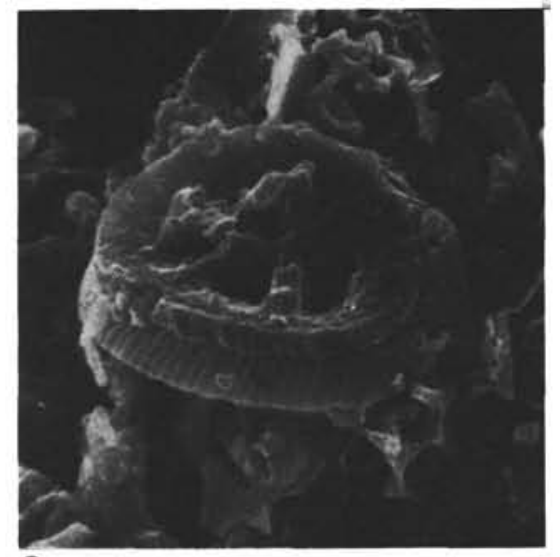

6

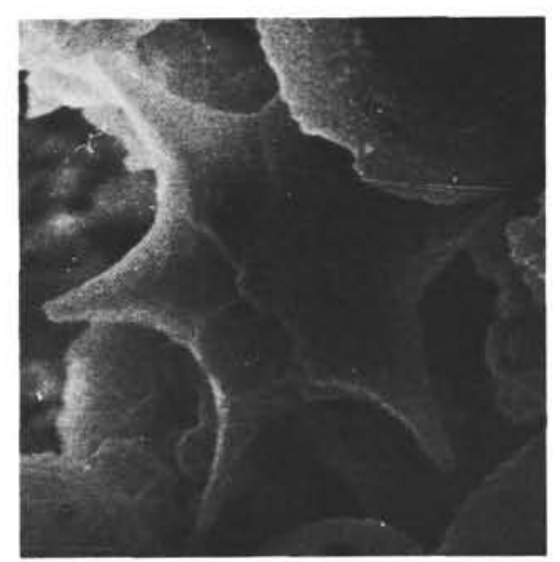

9

Plate 1. Eocene and Oligocene calcareous nannoplankton. 1. Isthmolithus recurvus Deflandre, 1954, $\times 5000$, distal side; Sample $592-37, \mathrm{CC}$, upper Eocene, Zones NP19/NP20. 2. Chiasmolithus oamaruensis (Deflandre) Hay, Mohler, and Wade, 1966, $\times 5000$, distal side; Sample 592-37,CC, upper Eocene, Zone NP19/NP20. 3. Zygrhablithus bijugatus (Deflandre) Deflandre, 1959, $\times 5000$, side view; Sample 588C-11,CC, upper Oligocene, Zone NP25. 4. Cribrocentrum reticulatum (Gartner and Smith) Perch-Nielsen, 1971, $\times 5000$, proximal side; Sample 59237, CC, upper Eocene, Zone NP19/NP20. 5. Cycloccolithus floridanus (Roth and Hay) Müller, 1970, $\times 4000$, complete coccosphere; Sample 588C-11,CC, upper Oligocene, Zone NP25. 6. Chiasmolithus solitus (Bramlette and Sullivan) Locker, 1968, $\times 4000$, distal side; Sample 588C-19-1, 55-57 cm, middle Eocene, Zone NP15/NP16. 7. Discoaster wemmelensis Achutan and Stradner, 1969, $\times 8000$, distal? side; Sample 588C-19-1, 55-57 cm, middle Eocene, Zone NP15/NP16. 8. Discoaster $\mathrm{sp} . \times 8000$, distal side; Sample 588C-19-1, 55-57 cm, middle Eocene, Zone NP15/NP16. 9. Discoaster saipanensis Bramlette and Riedel, 1954, $\times 4500$, proximal side; Sample 592-37,CC, upper Eocene, Zone NP19/NP20. 


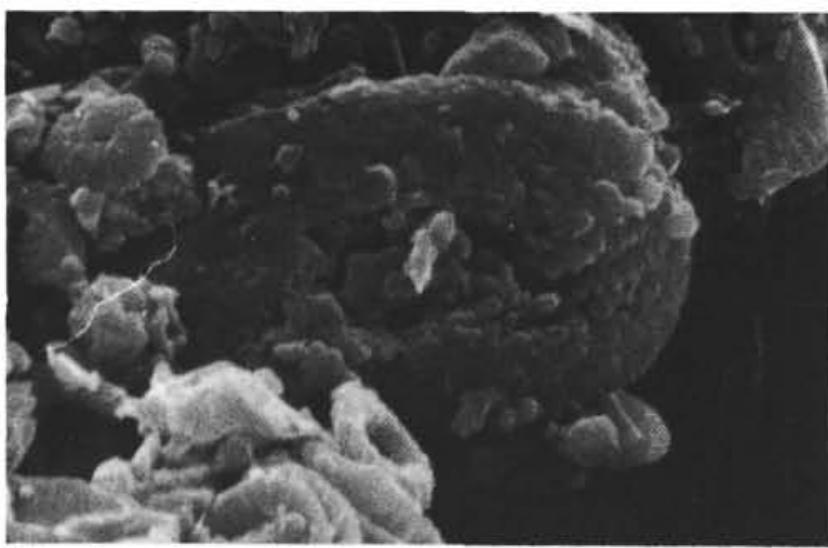

1

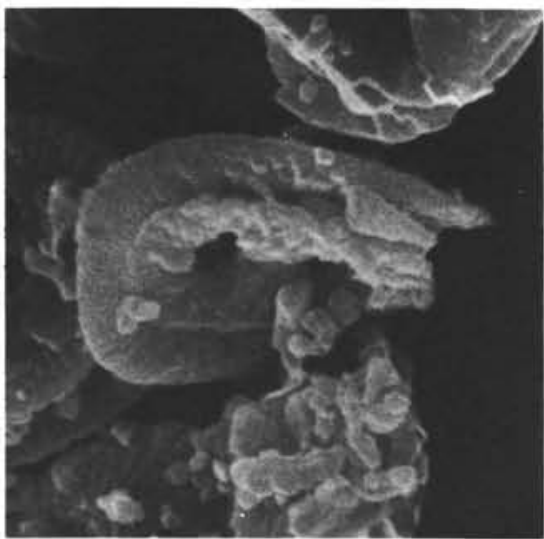

3

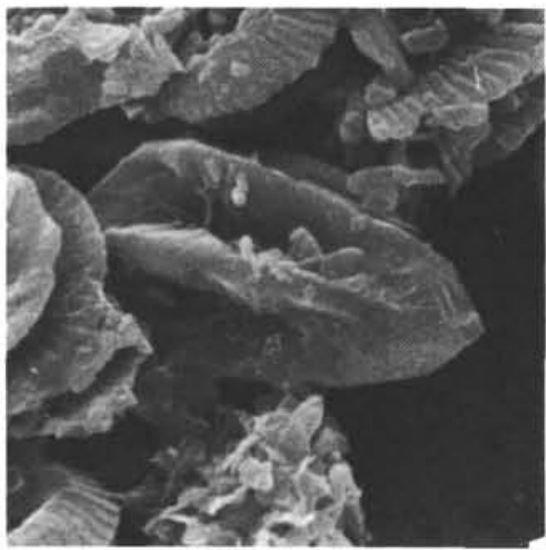

6

4

7

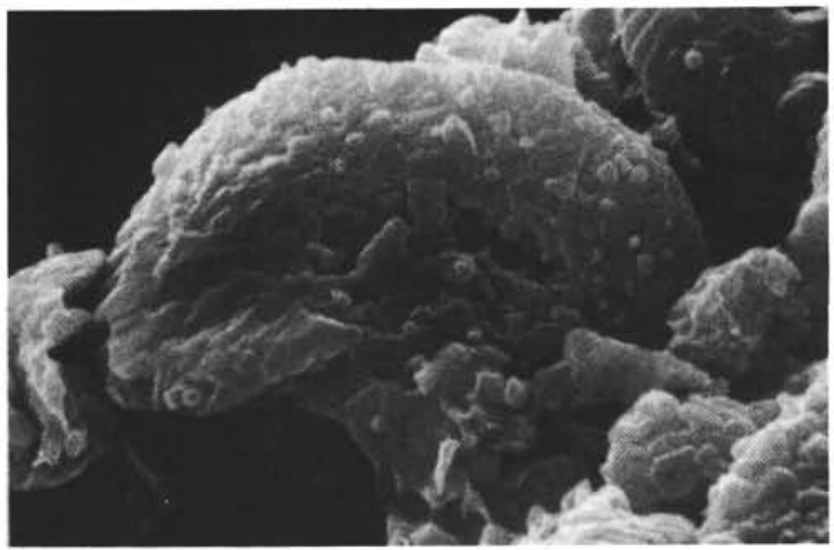

2
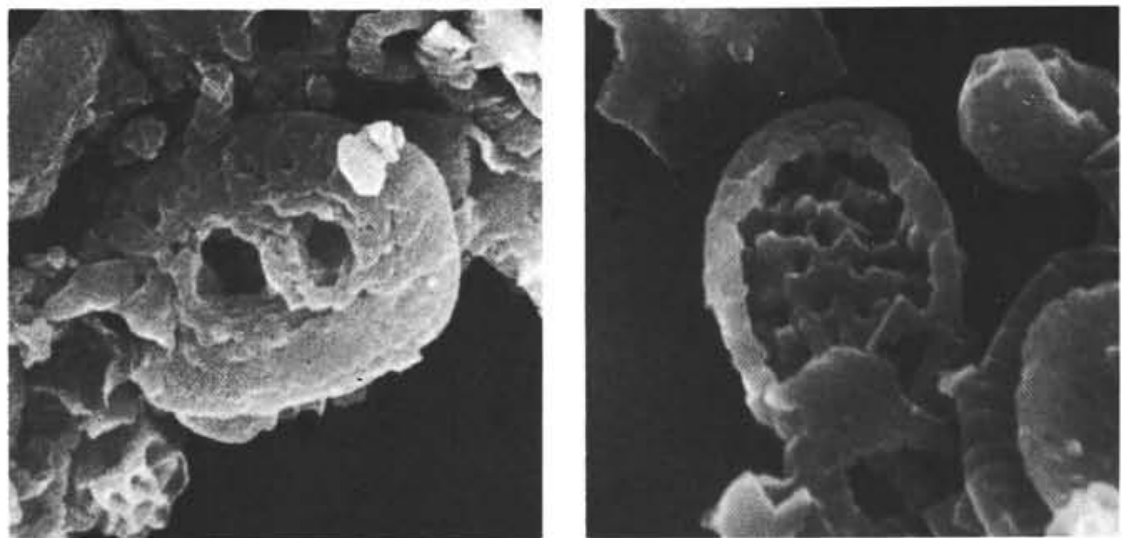

5

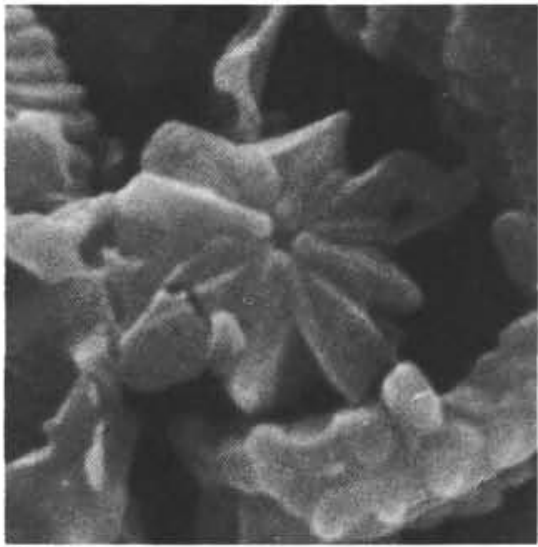

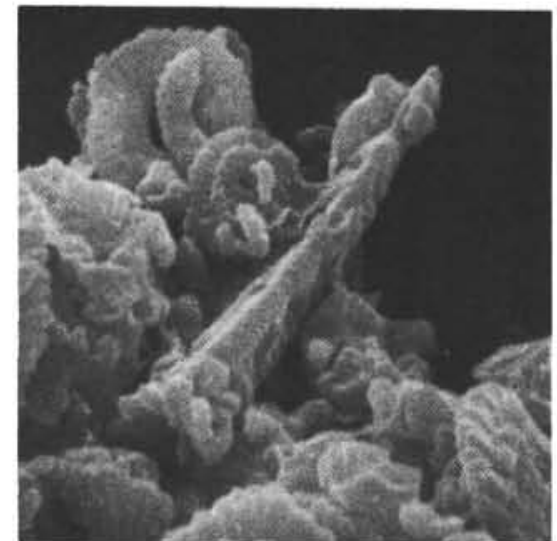

8

Plate 2. Eocene and Oligocene calcareous nannoplankton. 1, 2. Helicosphaera granulata (Bukry and Percival) Jafar and Martini, 1975, $\times 5000$, distal sides; Sample 588C-7-2, 0-1 cm, upper Oligocene, Zone NP25. 3, 4. Helicosphaera recta (Haq) Jafar and Martini, 1975, Sample 588C-7-2, 0-1 cm, upper Oligocene, Zone NP25, (3) $\times 5000$, proximal side; (4) $\times 4500$, distal side. 5. Discolithina punctosa (Bramlette and Sullivan) Perch-Nielsen, 1971, $\times 6000$, distal side; Sample 588C-19-1, 55-57 cm, middle Eocene, Zone NP15/NP16. 6. Triquetrorhabdulus milowii Bukry, 1971, $\times$ 4000, side view; Sample 588C-7-2, 0-1 cm, upper Oligocene, Zone NP25. 7. Sphenolithus elongatus $\mathrm{n} . \mathrm{sp} ., \times 10,000$, basal part; Sample 588C-7-2, 0-1 cm, upper Oligocene, Zone NP25. 8. Sphenolithus elongatus n. sp., holotype SM.B 13507, $\times 5000$, side view; Sample $588 \mathrm{C}-7-2,0-1 \mathrm{~cm}$, upper Oligocene, Zone NP25. 